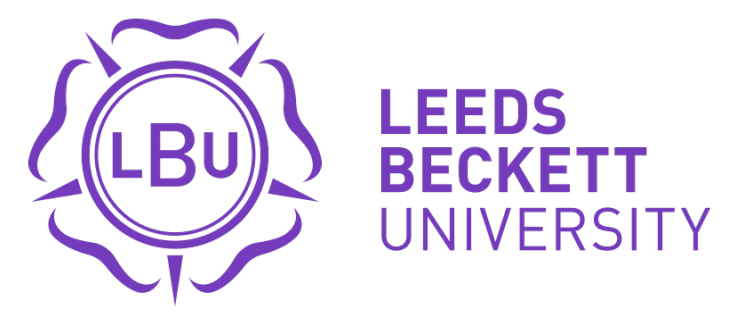

Citation:

Nasir, M and Al-Emadi, AA and Shahbaz, M and Shawkat, $H$ (2019) Importance of oil shocks and the GCC macroeconomy: A structural VAR analysis. Resources Policy, 61. pp. 166-179. ISSN 0301-4207 DOI: https://doi.org/10.1016/j.resourpol.2019.01.019

Link to Leeds Beckett Repository record:

https://eprints.leedsbeckett.ac.uk/id/eprint/5750/

Document Version:

Article (Accepted Version)

Creative Commons: Attribution-Noncommercial-No Derivative Works 4.0

The aim of the Leeds Beckett Repository is to provide open access to our research, as required by funder policies and permitted by publishers and copyright law.

The Leeds Beckett repository holds a wide range of publications, each of which has been checked for copyright and the relevant embargo period has been applied by the Research Services team.

We operate on a standard take-down policy. If you are the author or publisher of an output and you would like it removed from the repository, please contact us and we will investigate on a case-by-case basis.

Each thesis in the repository has been cleared where necessary by the author for third party copyright. If you would like a thesis to be removed from the repository or believe there is an issue with copyright, please contact us on openaccess@leedsbeckett.ac.uk and we will investigate on a case-by-case basis. 


\title{
Importance of Oil Shocks and the GCC Macroeconomy: A Structural VAR Analysis
}

Nasir, M.; Al-Emadi, A.; Shahbaz, M.; Shawkat, H.

\begin{abstract}
This study is an endeavour to analyze the influence of oil price shocks on the macroeconomy of the Gulf Cooperation Council (GCC) member countries (Bahrain, Kuwait, KSA, Oman, Qatar and UAE). By employing a structural Vector auto-regression (SVAR) model for period 1980- 2016, our key findings suggest that there are significant positive effects of oil price shocks on the GDP, inflation and trade balance of those countries. The findings, however, show substantial heterogeneities in the responses of the GCC members to oil shocks, which suggests the presence of idiosyncrasies in the underlying structure of their economies and differences in the degree to which these economies are dependent on oil revenues. In terms of inflation, there are also major differences in the intensity of the impact of oil shocks on the overall price, which implies that the GCC monetary policies might face a different genre of challenges to attain price stability in the face of those shocks. Our findings have profound policy implications in terms of diversifying the economies of the GCC countries and efforts to decrease the sole dependence on oil revenues.
\end{abstract}

Keywords: GCC, Natural Resources, Oil Price Shocks, Trade Balance, Inflation, GDP, SVAR Model.

JEL codes: F14, F15, F43, E31, Q41, Q43 


\section{Introduction}

Oil is undoubtedly the most important and internationally traded commodity due to its significance in production processes as well as to its share in the global trade. The total size of the global oil market is approximately over US\$1.7 trillion (EIA, 2016). However, the significance of oil varies among countries; depending on how much their economies are dependent on oil. In this regard, the Persian-Arabian Gulf is the region that is very highly oil dependent, and thus is affected by its price dynamics. The Gulf Cooperation Council (GCC) is an important economic and political block in the oil-rich Gulf region ${ }^{1}$. The members of the Council are major global exporters of oil and natural gas since the historic discovery of oil in the 1930s in Saudi Arabia (Feldman, 2017). The GCC countries are considered as very important oil suppliers in the global market, and concomitantly, they have become the focus of geopolitical debates since the exploration started in these countries (Sturm, et al., 2008). Since each individual state controls oil fields, oil is the biggest source of revenues for the governments of the GCC members. Nevertheless, despite the mutual importance of oil and petroleum, a common challenge faced by the entire GCC member since their inception and discovery of oil was to how to manage their revenues and diversify their economy. On this aspect, there are some differences in the strategies of these countries as some countries devote more efforts to diversify their economies by making investments in the non-oil sector of the economies.

In the last few decades, the global oil market has experienced a number of booms and busts and each cyclical swing has idiosyncratic implications for the GCC countries. Despite the political unrest associated with wars in the Middle East, the GCC countries have successfully maintained political stability ${ }^{2}$. However, despite being members of a unified economic and political block, the GCC members differ from each other in various aspects, specifically in terms of their economic development. A depiction of this phenomenon is prima facie evident in Figure 1.

\footnotetext{
1 The members of the GCC includes Bahrain, Kingdom of Saudi Arabia (KSA), Kuwait, Oman, Qatar, and United Arab of Emirates (UAE).

2 There have been wars between Iran and Iraq in 1980s, Iraq and Kuwait in 1990s and Iraq's US-led invasion in 2003 and sanctions on Iran.
} 


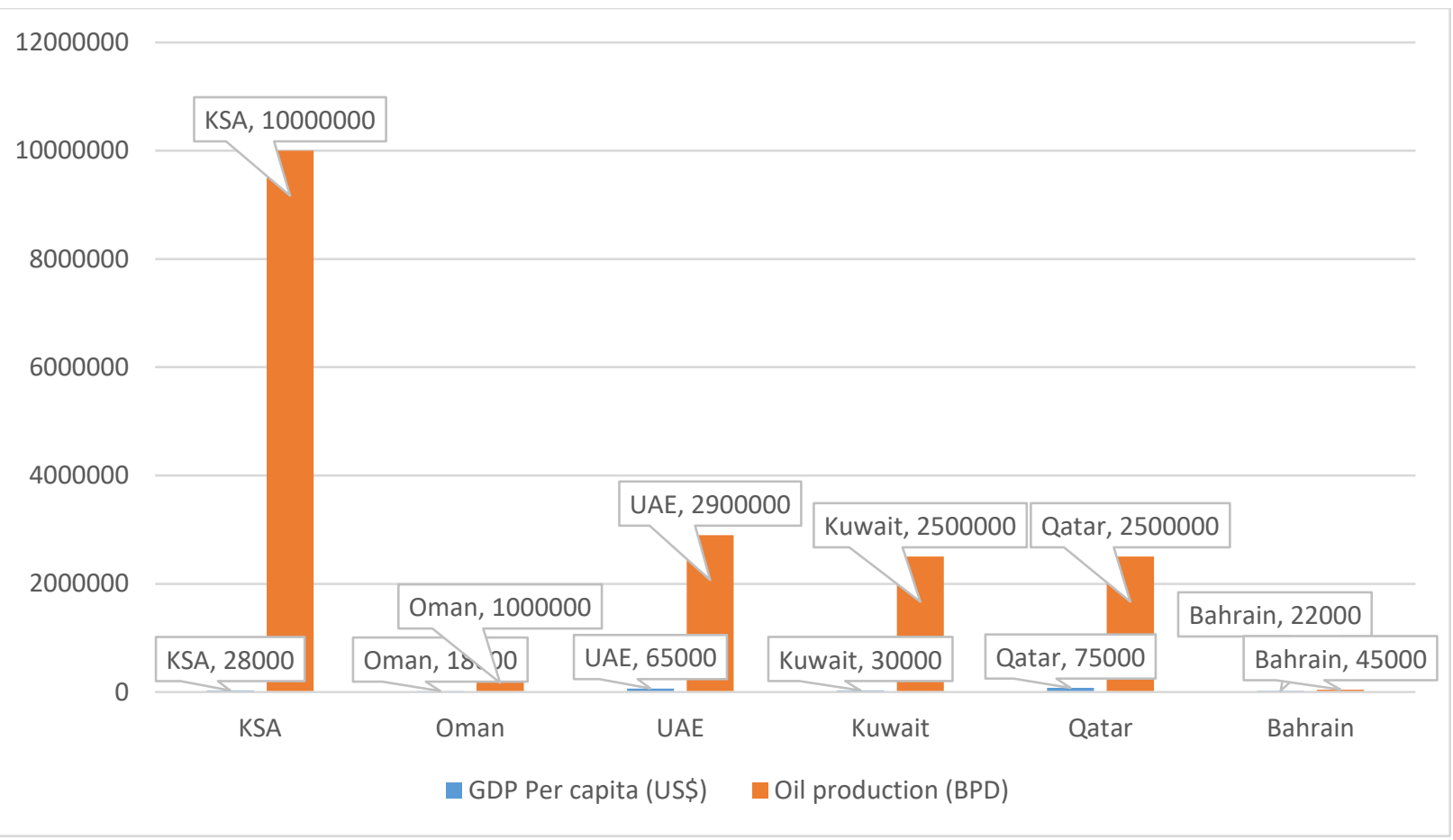

Figure 1: GDP Per Capita (US\$), Oil Production (Barrels per Day) in the GCC. Source: Statista (2016).

Concomitantly, the differences in the level of economic development could lead to various asymmetries in the response of these economies to oil shocks. However, the existing literature on the subject of oil shocks does not offer much insight about the GCC countries' economies and particularly heterogeneities in these economies and implications of oil shocks in this context. Specifically, for the domestic economy of these countries and the factors which can depict the domestic economy for instance economic growth (GDP) and price levels (inflation) and the external (trade) balance of these economies. Most of the studies which focused on the GCC countries and oil shocks, discussed the effects on either banking sector (Khandelwal et al. 2016) or/and stock market (Maghyereh and Al-Kandari (2007), Fayyad et al. (2011), Arouri and Rault (2012) Ulussever and Demirer 2017). The limited evidence which acknowledged the importance of oil shocks for the real economies of GCC has mostly focused on the causes of oil price fluctuations rather on their impacts and implications for the GCC economies (see for instance, Stern (2011), Tverberg (2012), Arezki and Blanchard (2014), Tokic (2015) and Kallis and Sager (2017). Similarly, some studies focusing on single countries did not take into account the internal (prices and growth) and external (trade) balance. For instance, Eltony el al (2001) only focused on Kuwait and did not 
analyse the impact on GDP and trade balance and considered other factors. In a recent study, Albaity and Mustafa (2018) using monthly data on Industrial production as a proxy for GDP and an atheoretical framework (Cointegration) did not find a significant impact of oil shocks on Industrial Production of a number of GCC countries. This can also be associated with the small period of analysis they focused on and can also be down to the proxy of economic growth for which they used industrial production (with some missing observations ) which may not be the most appropriate measure. Similarly, using simple regression and just fifteen-year annual data on the current account balances of GCC, the study by Vohra (2017) reported inconclusive and insignificant impact on the Bahrain, KSA and UAE which is counterintuitive. Perhaps, on the subject, the study for which parallels can be drawn is by Nusair (2016) which is the only study to best of our knowledge which considered the GCC as a block and employing a NARDL framework investigated the impact of oil shocks on the GDP only. Their results suggested that the positive oil shocks had a positive and negative oil shocks had a negative impact on GCC countries GDP, although the results were only significant for Kuwait and Qatar in case of negative shocks. Concomitantly, to fill the caveat in the existing body of knowledge, it requires a study on the impact of oil shocks on the GCC countries which take into account the international balance (GDP and Inflation) as well as external (Trade) balance. This is also the main aim and objective as well as the motivation and rationale for the subject treatise.

An important aspect to emphasize here is that one may argue that as the GCC countries are net oil exporters, there are differences between oil-importing and exporting countries (Kilian et al. 2009 and 2011, Narayan and Sharma 2011, Le and Chang 2013, Cashin et al. 2014, Rafiq et al. 2016). Hence, it can be assumed that their economies shall behave like any other oil-exporting country. However, such an analogy would be at least an oversimplification as the effects of oil shocks could vary from country to country due to their differences in economic structure, energy consumption and dependence on the international energy market (Wu et al., 2010). In this aspect, the empirical study by Wang et al. (2013) shows that there are significant differences in the impact of oil prices shocks on oil-importing and -exporting countries as well 
as there are differences in terms of oil dependency. Nonetheless, there are also crucial differences within the oil-importing and oil-exporting economies as these two groups of economies may respond very differently to an oil shock (see Nasir et al, 2018). Concomitantly, this appears to be a caveat in the existing body of knowledge and creates the scope and rationale of the subject endeavour. Therefore, this study focuses on analyzing the impact of oil shocks on the macroeconomy of the GCC countries.

Specifically, we focus on the impact of oil shocks on the domestic macroeconomic factors (Growth and Price Level) and the external (trade balance) position of the GCC economies. A comparative analysis of these economies in response to the oil shocks and especially the said internal and external macroeconomic factors will provide us with a deep insight into their strength and vulnerabilities to oil price dynamics. In so doing, we employ a Structural Vector Autoregression (SVAR) model on the data from 1980 to 2016 of the GCC countries. Our key findings suggest that although the oil price shocks are important for all the member GCC countries, there are major differences among the responses of these countries to oil shocks. It turned out that KSA which is also the largest oil exporter among the GCC countries and the world is also the one that is enormously affected by the oil shocks. The effects are explicitly shown in KSA's economic growth, trade balance and inflation. The findings for Bahrain suggest that the oil shocks have a greater impact on GDP and trade balance in terms of persistence, whereas the effects on inflation are more pronounced than on KSA. However, in terms of duration, the effects are rather short-lived. In the case of Kuwait, the oil shocks are even more persistent than for KSA and Bahrain in terms of output growth and trade balance, but for inflation, the impacts of oil shocks are very short-lived.

The results on the impact of oil shocks on economic growth suggested that the impact is largest for Kuwait followed by Bahrain and KSA in terms of severity of the oil price shocks and sensitivity of these economies to it. Economic growth in these three countries showed by and large more sensitivity to the oil shocks than other GCC countries. Similarly, the trade balance also shows a positive and prolonged response to the oil price shock. The impact on inflation is fairly modest probably due to the high proportions of investments of oil proceeds overseas. The empirical findings on Qatar show that the oil price shocks have 
positive yet very mild effects on economic growth, trade balance and inflation. Lastly, results on the UAE suggest that the price shocks have positive effects on economic growth, trade balance and inflation. However, for trade balance and inflation, the influence is short-lived. On the whole, the findings suggest a major heterogeneity in the response of GCC economies to oil shocks which have profound implications for the trade, fiscal and monetary policy responses and efforts towards the diversification of these economies.

The remainder of the paper proceeds as follows. Section 2 will provide a critical review of the existing evidence on the subject. Section 3 sets out a Structural Vector Autoregression (SVAR) model as a means to analyze the association between the oil shocks and the GCC economies and their aspects of interest the findings of analysis will be presented in Section 4. Section 5 concludes the paper 5 .

\subsection{Oil Shocks \& the Macroeconomy}

When it comes to international trade, the GCC countries are naturally endowed with two factors endowment, i.e. oil and gas, and have a comparative advantage in their production which are their major exports. However, their exceedingly over-reliance on the single commodity can also have implications, particularly if the price fluctuates in the international market. The global supply and demand forces play an important role in determining the oil price. Historically, there have been considerable fluctuations in the oil price, making some periods beneficial to the exporters while the downturns have been potentially more beneficial to the importing countries. Given the fact that a number of large oil- producing countries are situated in the Gulf, the political instability in this region results in oil prices dynamics in the international market (Baumeister, 2016). An example of it was the 1970s oil shock or events of 1980s, which lead to a sharp price fall (see, Macalister, 2011, Verleger, 1980). In the recent years, the global oil market faced a large slump where the price dropped from US\$ 100 per barrel to US\$ 27, according to Hou et al. (2015) this was the sharpest drop in the price of oil since 2008 which was associated with the Global Financial Crisis and great recession (Hou et al. 2015). Although, for the importing economies, such a fall in the price might be beneficial, on contrary, for the exporting economies like the GCC it could have detrimental 
implications (Sfakianakis, 2014). The major factors that dragged the oil price down are obvious and to large extent, there is a consensus of analysists on them. For instance, it is attributed to the decline in the pace of economic growth in large economies like China and the United States which are also the largest consumer of the oil (Bordoff and Stock, 2014) which concomitantly leads to the decrease in the demand of oil (Baumeister, 2016). In addition to these factors, some analysts also suggested that the increase of suppliers who are non-OPEC members have also played a significant role in falling prices (Husain, 2015). Nonetheless, Fattouh and Sen (2016) suggested that the refusal to reduce the price by big OPEC and GCC members like KSA has also led to a low price regime. Putting it simply, there could be a number of factors coming from the demand or supply side of the equation which does affect the oil prices, some of these factors may or may not be manageable by the GCC countries. However, the main question is how their economies respond to these shocks and an understating of the transmission of these can then lead to appropriate policy responses.

2.1.1 Economic Growth: The existing evidence on the nexus between the economic growth and oil prices suggests that the dynamics of the oil prices substantially contributes to the changes in the Gross Domestic Product (GDP). On this aspect, in an empirical study on China, Japan and the United States, Hesary and Yoshino (2015) investigated the association between oil prices and GDP. They found an inverse relationship between the GDP growth and oil prices. This led them to conclude that the negative association was due to reason that these economies were oil importers. However, Roubini and Setser (2004) argued that the impact of an oil shock on the economy and its effects depend on a number of factors, for instance, size of the shock, its persistence, the structure of the economy and macroeconomic policy response. For instance, in a scenario where the net import of the oil is zero and we witness a change in the price (decrease), it might be that the GDP is not influenced by the change. On the other hand, if the net import of oil increases while the price falls, it might be that we still witness a negative effect on GDP and increase in the import

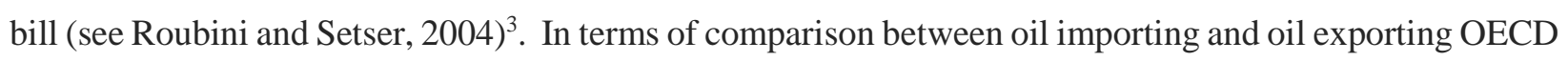

\footnotetext{
${ }^{3}$ Somewhat similar to Marshal-Learner Condition.
} 
countries, Rebeca and Sánchez. (2005) examined the relationship between oil price shocks and GDP. Their finding showed that there is a positive relationship between oil price shocks and GDP growth in some of the oil exporting countries. However, for the importing countries, there was a negative relationship between GDP and oil price shocks. There is also some evidence on the impact of oil prices which suggests asymmetric effects of oil shocks. For instance, Herath (2015) on the impact of oil prices reported that the negative oil price shocks have a larger impact on the Sri Lankan GDP, while the positive oil shocks have a smaller impact. Similarly, in another study by Farzanegan and Markwardt (2009) on Iran (an oil exporter) it was reported that during the positive oil price shocks have a larger positive impact on the Iranian GDP than the negative oil shocks which have a negative but smaller impact on GDP. Among other notable studies on the impact of oil price shocks on the GDP, Kim and Willett (2000), Dornbursh et al (2001), Glasure and Lee (2002), Jimenez-Rodriguez and Sanchez (2005), Tang et al (2010), Azin et al. (2015) and Onour (2016) all reported negative effects on the GDP.

2.1.2 Inflation: Oil being an important ingredient in the production process as well as a major constituent of the household consumption basket implies that any increase in the price of oil would have a crucial effect on the overall price level. In this regards, Leblanc and Chinn (2004) and most recently Choi et al (2018) argued that the higher rate of inflation can be a consequence of high oil prices. They argued that due to the increase in the price of oil, the cost of production for firms' increases which leads them to charge higher prices for their products and cost-push inflation. Hence, if the non-energy prices are held constant, such a scenario can lead to high inflation at the prevailing level of aggregate demand which can further take the economy into recession". Moreover, Cologni and Manera (2008) argued that due to the increase of the cost of products that work with oil derivatives, the increase in oil prices result in an increase in prices of goods to the consumers, concomitantly, price level increases lead to an overall increased rate of inflation (demand pull inflation). In evidence from Turkey, Gokmenoglu et al (2015) reported a long-run relationship between oil price, Inflation, GDP and Industrial production, though only Industrial production showed significant (Granger) causal relationship with oil prices. In evidence from China which is one of the major oil 
importers, Tang et al. (2010) reported a positive impact of oil shocks on inflation whereas, Wu (2011), showed that the oil price increase, in fact, leads to a drop in the inflation rate. Similarly, the evidence on exporting countries is also mixed. For instance, on Russia, which is one of the largest producers like GCCs, Rautava (2004) and Kuboniwa (2014) reported positive, but contrarily, Benedictow et al. (2013), Dülger et al. (2013) and Mironov and Petronevich (2015) reported negative effects. They argued that as the energy prices increase, appreciation of the Ruble could have harmful effects on the Russian economy (Dutch disease), furthermore, there could also be substitution and income effects for non-oil producers and consumers. Similarly, Idrisov et al. (2015) suggested that the impact of oil prices changes on Russian economy has actually decreased as Dreger et al. (2016) reported that there exists a very strong association between oil prices and the Russian economy. These contrasting results further strengthen the notion that drawing universal inferences based on the fact that the countries are oil importing or exporting will not be a cogent practice. In contrast, specific to the GCC countries, Qaiser, et al. (2016) reported that the demand for the oil is price inelastic but income elastic in the short as well as the long run. Furthermore, that there was a significant association between the income and oil prices. Specifically, in response to the income growth, the demand for oil increased while the demand for the oil decreased in response to the increase in the price level. It implied that the increase in the price of oil might have idiosyncratic implications for the GCC economies which the subject study is endeavouring to explore.

2.1.3 Trade Balance: Due to the reason that oil is a major internationally traded commodity, it has implications for the international trade and the trade balance of the importing and exporting countries. The oil shocks can affect trade balances of countries, firstly it is through the terms of trade and secondly via wealth effects (Amano and Van Norden, 1998). It is intuitive to expect some heterogeneity in the response of the external position of different economies to oil prices shocks, contingent on their economic structure and net trade position in oil. There is a difference in the effect on how oil prices affect trade balance due to oil supply and demand shocks, there is also a difference in the way, oil shocks have an impact on the importers and exporters (Kilian et al. 2009, Le and Chang 2013, Rafiq et al. 2016). On the impact of oil 
prices shocks on net-oil exporter's trade balance, it has been often suggested that the impact shall be positive (Rafiq et al. 2016). However, there are varies channels through which the oil shocks transmits. In particularly to the external balance, Le and Chang (2013) pointed out that an increase in oil prices is not all positive, but with an increase in oil prices, the pressure is exerted on the inflation in global market making imports more expensive for oil-importing and oil-exporting countries ${ }^{4}$. Furthermore, the demand for oil will decrease which would affect the trade balance of an oil-exporting country (demand effect) and also an increase in oil prices would have a negative effect on oil-importing countries, as it will slow down their production processes and imports which would then again affect the trade balance of an oil-exporting country (supply effect). Based on this logic, we can infer that an oil exporter's gain from an increase in oil prices relies heavily on the interdependencies of the revenues, demand and supply effects (Le and Chang 2013, Cashin et al. 2014). Moreover, even if there is an overall positive impact from the increase in oil prices for the oil-exporting country, there are counteracting negative concerns such as the Dutch disease and dependency on trading partners. As for oil-importing countries, some studies have documented the negative effect of the increase in oil prices on their terms of trade (Kim and Loungani, 1992). A later study by, Tiwari et al (2014) reported that positive oil shocks have significant negative effects on the Indian trade balance. The increase in the oil prices leads to increase the Indian trade deficit. However, in case of the USA which is also a major oil importer Jackson (2016) reported that there is no evidence that the decline in oil price contributes to decreasing the trade deficit, if fact, there is some evidence that suggests that decrease in oil prices, may in fact, increase the trade deficit. In the case of the GCC, the oil is either the most important export or at least one of the most important export of all the countries. Hence, it is obvious to expect a positive effect of an oil price shock on the trade balance of GCC countries, though a) it depends on the price elasticity of exports and b) there could potential heterogeneities in the response of trade balance as well. Perhaps, the fact that the GCC countries are major net oil exporters does not imply that there is

\footnotetext{
${ }^{4}$ Specifically, in response to the oil shocks and resulting inflation, monetary authorities would have to increase the interest rates to cope with inflation pressure which can lead to a decrease in consumption, investment and economic slowdown (Ferderer, 1996).
} 
shall be homogeneity in the response of their economies to the oil shocks. On this aspect, a study by Nasir et al (2018) on BRICS economies reported considerable heterogeneities between and within the oil exporting and oil importing BRICS economies. Specifically, their results showed that the oil price shocks transmissions to economic growth, inflation and trade balance varied between the oil exporting Brazilian and Russian economies.

\subsection{Oil \& GCC countries}

The GCC countries hold a major proportion of the global proven oil reserves, the depiction of which is prima facie in Figure 2.

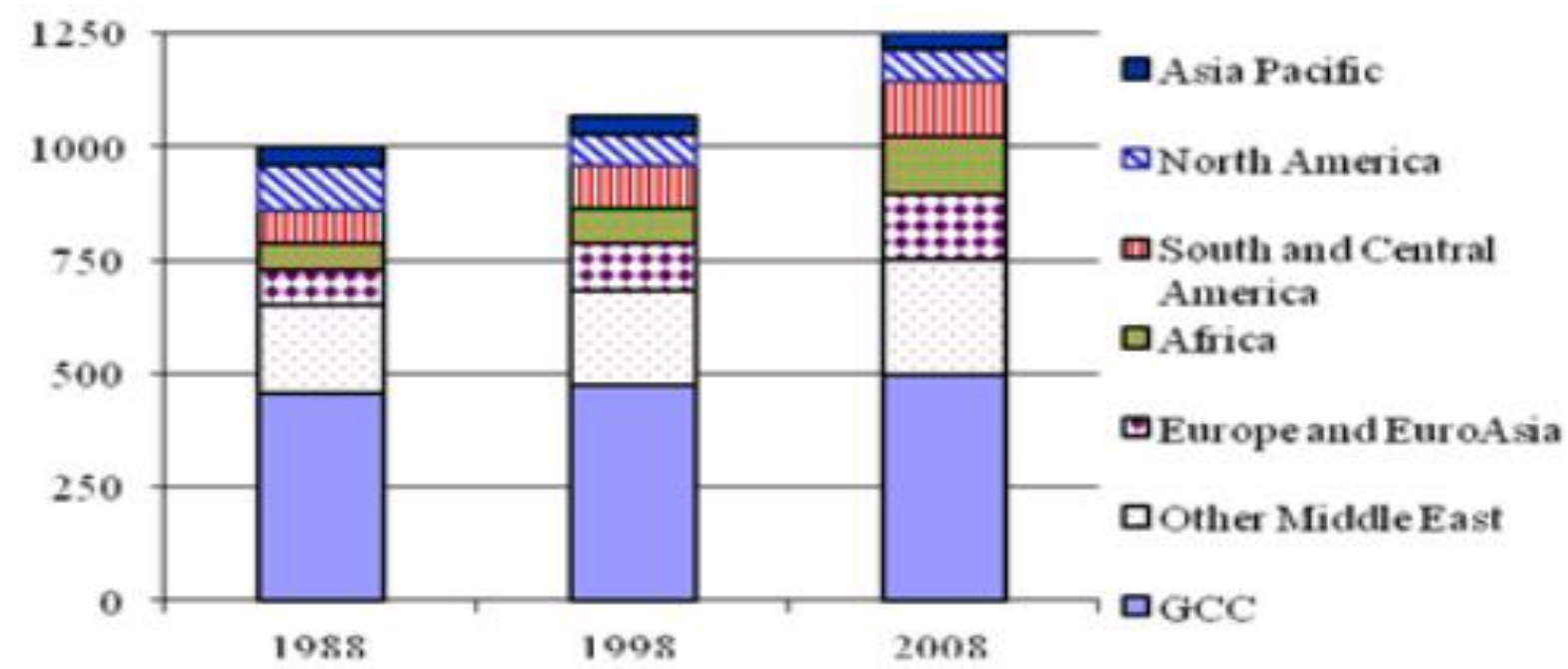

Figure 2. Global Oil Reserves (proven) by region (thousand million barrels). Source: BP Statistical Review 2009.

This idiosyncratic endowment of the natural resources in the form of oil and petroleum has profound implications for the macroeconomy of these countries.

Saudi Arabia: The Kingdom of Saudi Arabia (KSA) is one of the largest oil producers and net exporters in the world. The importance of oil for the KSA's economy is prima facie evidenced in the fact that most of its fiscal commitments (80\%) and GDP (45\%) depend on the oil revenues. Capitalizing on the favourable global oil price regime in the past, KSA has accumulated high foreign reserves; there are concerns that the 
economic stability may become difficult to manage in the face of falling prices (see Bremmer, 2016; Nakov and Nuño, 2013). Nonetheless, in the absence of a developed tax system, the social and public expenditure is highly centred on oil for funding. Concomitantly, the low oil prices may not yield the required revenues to balance the books and it requires the government to either restructure the tax system or restructure its spending (see Simmons, 2013, Bryant, 2015). In this regard, the World Bank (2016) also expressed concerns that the low price regime can lead to not only a decline in consumption but can also have negative consequences for investment (Gross fixed capital formation). Similarly, Algahtani (2016) argued that the recent increase in investment by the private sector facilitated by the government is appreciable, however, in a scenario where the disposable income declines due to the decline in the oil revenues it might be that business environment seemed to become unfavourable which may then hinder the investment. On the contrary, a study by Thompson, et al (2012) argued that the future is rather brighter as KSA has been on the route to the diversification of its economy and industries as well as a reduction in oil dependency. Nonetheless, that argued that the accumulation of reserves could help KSA to guard against negative oil shocks. On this aspect, where Alodadi and Benhin (2015) supported the notion that the price shocks are not likely to affect KSA in the short run. However, they also cautioned that the KSA might not be able to support it's domestic industry the way it has been supported in the past. Added to that, the industry in general and manufacturing sector, in particular, will be adversely affected and also that there has already been a considerable support to the non-oil industries and export promotion which raises questions on the room for further industrial support.

Oman: The economy of Oman has the lowest per capita in the GCC. In the past, oil production had been reduced due to the low and infeasible oil prices which led to unemployment and reduced profitability. This is prima facie evidence of the fact that the negative oil shocks can have huge adverse implications for the Omani economy (Masan, 2016). According to Dutta et al (2017), negative oil shocks can lead to a sharp decrease in fiscal spending, private investment and disposable income. In this context, it has been urged by some scholars, that a prudent fiscal management and diversification of the economy must be a top priority 
of the government (see, for instance, Jouini and Harrathi, 2014). The historical evidence suggests that the decrease in the prices in the past, specifically in 1986 and then 1990 were followed by recessions. The government has launched economic reforms and diversification program called Vision 2020 in 1996. On this aspect, one important factor to consider is that the dependence of the Omani economy on oil can influence its efforts toward diversification. Specifically, in the face of negative oil shocks, the financial commitments to investment in diversification projects can also become difficult to honour. This led Murshed and Nakibullah (2015) to caution that if the global oil prices do not regain a favourable level for producers, it may hamper development efforts. More than two decades after the start of Vision 2020, with the benefit of hindsight, we can gauge the success of the diversification efforts by analysing the implications of oil shocks for the Omani economy.

United Arab Emirates: The UAE has fairly widespread sources of revenues as compared to the other GCC counterparts. This is evident in the fact that business and trade contribute to the national income by a considerable proportion. As an effort towards diversification and less reliance on oil, the government has scrapped some of the subsidies to the household (Business Monitor International, 2016). To some extent, the efforts have been fruitful as it is evident in the fact that by 2015 , only $1 \%$ of the population was employed by the mining sector whereas retail, tourism and hospitality, transportation and airlines, and wholesale trade seemed to be the sector absorbing most of the labour market capacity. These economic developments have been the outcome of the policy of investment in the non-oil sector, including real estate and the financial sector. Similarly, the tourism sector has also been the focus of government attention and incentives have led to an increase in the number of tourists (Mimouni, et al., 2016). Undoubtedly, the diversification of the economy and facilitating business environment has increased UAE's ability to attract foreign investment and increase its revenues, this is in addition to the fact that contrary to some of its GCC counterparts, UAE had started to charge an income tax which provides its considerable fiscal space. (Mahboub and Ahmad, 2016). Contrary to 1970s when the oil was attributed to 90\% of the UAE's GDP, as it stands, it only accounts for $30 \%$ of the countries national income. However, despite the development 
and growth of economy and efforts towards diversification, oil is still an important and crucial factor for the economy and fiscal capacity. Therefore, it is still vital to consider the implications of the oil shocks for the UAE economy. Nonetheless, as some scholars (see, for instance, Berument, et al. (2010), Gülay, and Pazarlioğlu, 2016) quite intuitively argued that the favourable level of global oil prices will be helpful in continuing the growth, development and diversification efforts of UAE economies

Kuwait: The State of Kuwait's economy is heavily dependent on oil which is manifested in the fact that its revenues account for half Kuwaiti GDP and over $90 \%$ of the government fiscal space is provided by the income from oil (Hutt, 2016). Comparatively, Kuwait had been enjoying a fiscal surplus in the Pre 2014 oil boom which also increased the public spending, however, the fall in the prices post 2014 boom had some negative consequences which are evident in the substantial fall in the public spending (The World Bank B 2016). In terms of diversification, there is no evidence to suggest that the efforts have been remarkably successful. On this aspect, Economou and Agnolucci (2016) argued that the Kuwaiti economy is largely dependent on a single industry and source of revenue i.e. oil. Concomitantly, some scholars, for instance, Bohi (2016) argued that despite the strong fiscal outlook, a prolonged and persistent low oil price regime can severely affect the economy. Hence, the solution suggested by studies like Sbeiti (2016) is the diversification of the Kuwaiti economy. An important point, to note in this regard is that the low oil prices can also be detrimental for the private sector (profits) and household income in Kuwait (for discussion, see Bataa, 2010; Fayyad and Daly, 2011; Boldanov, et al., 2016). Due to these concerns and recent low oil price regime, in order to diversify and develop the non-oil sector, the State of Kuwait has embarked on 5year reforms plan. This entails development of SMEs, prudent management of public finances, reforms of the labour market and public sector (Kennedy, 2016). These efforts are intuitive; however, according to the Institute of Banking Studies (2015) diversification may not make up for the loss of revenues due to the adverse oil price regimes and hence may negatively affect the economic growth. 
Qatar: The economy of Qatar is not solely dependent on oil. Despite the fact that oil is one of the major export, however, petroleum (crude and refined) only accounted for about $1 / 5^{\text {th }}$ of its exports. On the other hand, petroleum gas has a lion's share in the total exports which at the moment stand around 61\% (Atlas, 2017). This implied that the volatility and particularly the adverse oil shocks should have a milder effect on the economy of Qatar. According to Singh (2017), the fiscal management of Qatar's public finances is already conservative which implies that the decrease in oil prices may have minimal effects (Singh, 2017). In terms of diversification, efforts have been made by the government by focusing on infrastructure projects (Wahbah and Assaad, 2016). One aspect of that is the hosting of the football world cup in 2020 and the Olympics in 2020. This implies that in the coming years, infrastructural developments might lead to positive effects on economic growth.

Bahrain: The Kingdom of Bahrain's economy is largely dependent on oil production and refining. This is evident in the fact that it accounts for over $60 \%$ of total exports as well as $11 \%$ of GDP and $70 \%$ of the public revenue income. Similar to the other GCC counterparts, Bahrain has made diversification efforts by focusing on non-oil sectors, including finance, construction, production of aluminium, commercial and retail, and the manufacturing sector. In terms of fiscal stability, in recent years, Bahrain has faced increasing levels of sovereign debt (Manama, 2016). Bahrain has also embarked on a 5-year development plan in 2014 which would cost around US\$22 billion. Despite, the efforts towards diversification and economic development, in the current scenario, the oil prices still seemed to remain an important factor which can determine the success of these efforts as well as future growth (Kilian, 2014; Arouri, et al., 2011). In addition to the economic challenges, in the recent past, Bahrain has faced political instability and sectarian tensions. Although the political issues have been contained so far, the adverse oil price regime may aggravate the situation of the political economy. Nonetheless, it also limits the ability of important neighbours and fellow GCC countries like KSA to support Bahrain (Sahoo, 2015). Concomitantly, it appears that despite some progress and development of the non-oil sector, the political economy of Bahrain still seemed to be reliant on oil revenues. 
The brief discussion on the structure of GCC economies and importance of the oil sector in each is a prima facie reflection of the latter. However, the heterogeneities in the structure of these economies also merit an inquiry to better understand the differences in the response of these economies to oil shocks and concomitantly an appropriate policy response. The next section will shed light on the methodological framework we employed to gain this understanding.

\section{3 .1 Methodology}

We employed a SVAR framework to analyse the impact of oil shocks on the GCC countries. The SVAR is a dynamic empirical framework which possesses the ability to explain economic phenomena underpinned by underlying economic theories. This feature makes it particularly useful for the policy and macroeconomic shocks such as oil shock. In this regard, the IRF analysis is extremely helpful in tracking the impact of an exogenous shock on the response variables in the system. After gathering ample insight through IRF analysis into the phenomenon that where there are significant implications for the response variables and their dynamics due to such shocks, we will apply FEVDM analysis. The FEVDM is useful in explaining the amount of variation in the response variables we can attribute to the shock. The existing evidence and theoretical association between the oil shocks and macroeconomic factors such as GDP, inflation and trade balance have been discussed at length in earlier passages of this treatise. The choice and application of SVAR framework to gain insight into the under analysis variables of interest in the GCC countries is similar to the studies which employed this framework for similar topics for different countries (For instance see, Bernanke et al., 1997; Peersman, 2005; Peersman and Van Robays, 2009; Kilian and Park, 2009; Park et al, 2011; Cunado and Gracia, 2015;). Concomitantly, in the employed SVAR framework, we will perform the impulse response function (IRF) analysis and Forecast Error Variance Decomposition (FEVD) analysis to investigate the impact of oil price shocks on the GDP, trade balance and inflation in the GCC countries. Furthermore, a comparison will be made; discussing how each country 
is impacted by the oil price shock will enable us to make policy recommendations. In the following lines, we will set out the SVAR framework.

\subsection{Structural Vector Autoregressive (SVAR) model}

Let's starts with a general specification of a SVAR model as follows;-

$$
A_{0}=A_{1} Y_{t-1}+\ldots \ldots \ldots \ldots+A_{p} Y_{t-p}+\varepsilon_{t}
$$

Where $Y_{t}$ represents $(n \times 1)$ vector of relevant variables including:

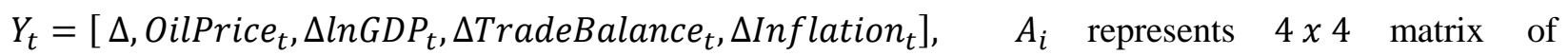
coefficients, for instance, $i=0,1 \ldots \ldots P$ and $\varepsilon_{t}$ is the vector or structural shocks which can be represented as $\left[\varepsilon_{t}^{\text {oilprice }}, \varepsilon_{t}^{G D P}, \varepsilon_{t}^{\text {TradeBalance }}, \varepsilon_{t}^{\text {Inflation }}\right.$ which are independent and identically distributed (I.I.D). The $\varepsilon_{t}$ is a vector of serially uncorrelated, $\left(E\left(\varepsilon_{t}\right)=0\right)$ and $\Sigma_{\varepsilon}=E\left[\varepsilon_{t} \varepsilon_{t}^{\prime}\right]=I$. The SVAR can be presented in the reduced form as follows;-

$$
\begin{gathered}
A_{0}=A_{1} Y_{t-1}+\ldots \ldots \ldots+A_{p} Y_{t-p}+\varepsilon_{t} \\
Y_{t}=A_{0}^{-1} A_{1} Y_{t-1} \ldots \ldots \ldots+A_{0}^{-1} A_{p} Y_{t-p}+A_{0}^{-1} \varepsilon_{t} \\
Y_{t}=B(Y) Y_{t}+u_{t} \\
\mathrm{~B}(\mathrm{~L}) Y_{t}=A_{0}^{-1} A_{1}(L) \\
\text { And } A_{0} u_{t}=\varepsilon_{t}
\end{gathered}
$$

Where $u_{t}$ are the innovation in the reduced form VAR and considered to be independent and identically distributed (I.I.D). $A_{1}(L)$ is the polynomial matrix in the lag operator.

\subsection{Identification and Restrictions}


For identification purposes, we imposed restrictions in our SVAR framework which are embedded and underpinned by the economic theory. In specific to this study, we apply the short run restrictions on the contemporaneous relationships among variables of interest. The current feedback effects are controlled by the short-terms restrictions so that the exogenous nature of the oil shocks and effects are determined in the subject case.

$$
\left[\begin{array}{cccc}
1 & 0 & 0 & 0 \\
a_{21} & 1 & 0 & 0 \\
a_{31} & a_{32} & 1 & 0 \\
a_{41} & a_{42} & a_{43} & 1
\end{array}\right]\left[\begin{array}{c}
u_{O P_{t}} \\
u_{G D P_{t}} \\
u_{\text {Trade }_{t}} \\
u_{\text {Inft }}
\end{array}\right]=\left[\begin{array}{cccc}
1 & 0 & 0 & 0 \\
0 & 1 & 0 & 0 \\
0 & 0 & 1 & 0 \\
0 & 0 & 0 & 1
\end{array}\right]\left[\begin{array}{c}
\varepsilon_{O P_{t}} \\
\varepsilon_{G D P_{t}} \\
\varepsilon_{\text {Trade }_{t}} \\
\varepsilon_{\text {Inf }}
\end{array}\right]
$$

The identification restrictions are underpinned by the economic theory that the global oil market is competitive and none of the GCC countries is in a position to influence the price of oil on its own. Nonetheless, the domestic output growth (GDP), trade position (Balance of trade) and dynamics of the domestic price level (inflation) are not strong enough to influence the global oil price setting, at least not in the short-run. On the other hand, the global oil price shocks are strong enough to have considerable implications for the GCC countries in the short as well as the long run. Given the fact that the data we will employ is annual data for thirty-six year which is ample time frame to present the short-medium term effects. Considering that the oil price shocks are treated as exogenous, the reduced form innovations for the oil shocks are equal to the structural innovations which can be presented as follows;

$$
u_{O P_{t}}=\varepsilon_{O P_{t}}
$$

On the contrary, the oil price shocks may have contemporaneous effects on the other variables. It is very intuitive identification condition as the increase in the oil price can lead to an increase in the cost of production. Furthermore, as the GCC countries are oil exports there could be price pressure through demand which also leads us to establish that there would be implications for the aggregate demand and specifically output growth here (GDP). However, we also expect the domestic price level to comparatively sticky and a slower adjustment compared to the domestic output and Trade balance. Lastly, the trade balance is also 
expected to be affected by the oil shocks given that the oil is the biggest export of the GCC countries. The reduced form innovations for the GDP, Trade Balance and Inflation takes the following representation:-

$$
\begin{gathered}
u_{G D P}=-a_{21} u_{O P}+\varepsilon_{G D P} \\
u_{\text {TradeBal }}=-a_{31} u_{O P_{t}}-a_{32} u_{G D P}+\varepsilon_{\text {TradeBal }} \\
u_{\text {Inf }}=-a_{41} u_{O P}-a_{42} u_{G D P}-a_{43} u_{\text {TradeBal }}+\varepsilon_{\text {Inf }}
\end{gathered}
$$

The implications of the functional form and specification of SVAR framework will be helpful to analyse the impact on oil shocks on the internal balance (inflation \& GDP) and external (trade) balances of the GCC countries.

3.4 Data: The collection of data on all the GCC economies for the longest possible period was a quite challenging task. The luxury of comparatively higher frequency and longer horizon which one can afford in the case of developed economies is not available in case of developing countries like GCC. However, we were successful in collecting the annual data for the GDP, inflation, trade balance, and oil prices from 1980 to 2016. The choice of time horizon is motivated by the availability of data. We endeavoured to employ the data with the longest possible time horizon. The main source of data collection was the Datastream. However, we still had some missing observations for the trade balance of Qatar and Bahrain in the 1980s. Concomitantly, we drew on the other reliable sources such as these countries official statistical agencies databases and trading economics database. We took the log of the GDP and oil prices but did not take the log of the inflation, as it was a percentage change. Except for KSA and Qatar, we did not take the log of trade balance because of negative values i.e. Trade Deficit.

\section{Analysis and Findings}

To start with, we performed the Unit-root tests to gain insight into the characteristics of data series as well as to determine the order of integration to find if the data is stationary or possess unit-root. For this purpose, 
we employed the Augmented Dickey-Fuller (ADF) with a structural break which is preferable to the simple ADF test as the simple test without considering structural break can give biased results (See Perron 1989).

\subsection{Unit-root Test}

The underlying data series of economic growth, trade balance, inflation and oil prices often exhibit structural shifts from their usual trend due to a number of reasons which we can categories into business and financial cycles. Considering this aspect, Ranganathan and Ananthakumar (2010) cautioned that in presence of such a structural break in a series, a unit root test which ignores accounting for the structural break can be biased towards null of random walk. This is due to the reason that if we condone the structural break, the random shocks are assumed to have a permanent effect on the system. Therefore, in this study, we are considering the aspect of structural breaks in the series. The date of the break was endogenously determined by using the data employed rather than a given date. We choose the date with the strongest evidence of a break. The alternative minimize and maximise options are provided to allow for evaluation of one-sided alternatives, and will produce different critical values for the final DF test statistic and tests with greater power than the non-directional alternatives (See Zivot and Andrews, 1992; Banerjee et al., 1992; and Vogelsang and Perron, 1998). The Augmented Dickey-Fuller test is applied to test the stationarity in the presence of break with both Additive Outliers (AO) and Innovative Outliers (IO) as defined by the seminal work by Fox (1972) and later by Tsay $(1988)^{5}$. The results are displayed in the Table-1 below:-

Table 1: ADF Unit Root Test with Structural Break

\begin{tabular}{|l|l|l|l|l|l|}
\hline Variables & $\begin{array}{l}\text { ADF } \\
\text { Statistic }\end{array}$ & Test & $\begin{array}{l}\text { Critical Value at } \\
\mathbf{1 \%} \text { Level }\end{array}$ & $\begin{array}{l}\text { Critical Value at } \\
\mathbf{5 \%} \text { Level }\end{array}$ & $\begin{array}{l}\text { P-values } \\
\text { LOG-GDP KSA }\end{array}$ \\
\hline Inflation KSA & -3.680 & -5.719 & -5.175 & 0.925 & 2010 \\
\hline Trade Balance KSA & -4.362 & -5.719 & -5.175 & 0.304 & 2007 \\
\hline LOGGDP UAE & -3.414 & -5.719 & -5.175 & 0.852 & 1994 \\
\hline Inflation UAE & -3.333 & -5.719 & -5.175 & 0.961 & 1999 \\
\hline
\end{tabular}

\footnotetext{
${ }^{5}$ On this aspect, assuming an AR structure with Gaussian noise, study by Fox (1972) pioneered the consideration of outliers within analysis of the time series. There were two overarching classifications of outliers' i.e. "Additive Outliers (AO) and "Innovative Outliers (IO). In the case of AO, only a single point is affected whereas in the case of $\mathrm{AI}$ an innovation to the process affects both an observation and the subsequent series.
} 


\begin{tabular}{|c|c|c|c|c|c|}
\hline Trade Balance UAE & -4.697 & -5.719 & -5.175 & 0.158 & 2013 \\
\hline LOGGDP Oman & -3.637117 & -5.719 & -5.175 & 0.99 & 2000 \\
\hline Inflation Oman & -4.846816 & -5.719 & -5.175 & 0.112 & 2006 \\
\hline Trade Balance Oman & -2.341015 & -5.719 & -5.175 & 0.99 & 2000 \\
\hline LOGGDP Kuwait & -3.438578 & -5.719 & -5.175 & $0.01^{*}$ & 1990 \\
\hline Inflation Kuwait & -6.307886 & -5.719 & -5.175 & $0.01^{*}$ & 1990 \\
\hline Trade Balance Kuwait & -3.884951 & -5.719 & -5.175 & 0.445 & 2000 \\
\hline LOGGDP Qatar & -2.322644 & -5.719 & -5.175 & 0.999 & 1994 \\
\hline Inflation Qatar & -4.804684 & -5.719 & -5.175 & 0.122 & 2006 \\
\hline Trade Balance Qatar & -3.968133 & -5.719 & -5.175 & 0.543 & 1998 \\
\hline LOGGDP Bahrain & -2.576808 & -5.719 & -5.175 & $0.01 *$ & 2000 \\
\hline Inflation Bahrain & -5.784763 & -5.719 & -5.175 & $0.01 *$ & 1986 \\
\hline Trade Balance Bahrain & -4.046629 & -5.719 & -5.175 & 0.490 & 1998 \\
\hline Oil Price & -3.321189 & -5.719 & -5.175 & 0.791 & 1994 \\
\hline \multicolumn{6}{|c|}{$1^{\text {st }}$ Difference ADF Test Statistics } \\
\hline LOGGDP KSA & -5.773142 & -5.719 & -5.175 & $0.01 *$ & 2010 \\
\hline Inflation KSA & -9.141416 & -5.719 & -5.175 & $0.01 *$ & 2008 \\
\hline Trade Balance KSA & -7.649398 & -5.719 & -5.175 & $0.01 *$ & 2010 \\
\hline LOGGDP UAE & -6.435619 & -5.719 & -5.175 & $0.01 *$ & 2007 \\
\hline Inflation UAE & -9.905301 & -5.719 & -5.175 & $0.01^{*}$ & 1985 \\
\hline Trade Balance UAE & -6.565792 & -5.719 & -5.175 & $0.01 *$ & 2009 \\
\hline LOGGDP Oman & -7.308590 & -5.719 & -5.175 & $0.01 *$ & 2013 \\
\hline Inflation Oman & -8.233598 & -5.719 & -5.175 & $0.01^{*}$ & 1986 \\
\hline Trade Balance Oman & -8.660240 & -5.719 & -5.175 & $0.01^{*}$ & 2010 \\
\hline LOGGDP Kuwait & -5.841719 & -5.719 & -5.175 & $0.01^{*}$ & 1991 \\
\hline Inflation Kuwait & -10.94556 & -5.719 & -5.175 & $0.01^{*}$ & 1990 \\
\hline Trade Balance Kuwait & -7.7608789 & -5.719 & -5.175 & $0.01 *$ & 2014 \\
\hline LOGGDP Qatar & -5.776069 & -5.719 & -5.175 & $0.01 *$ & 2014 \\
\hline Inflation Qatar & -9.889508 & -5.719 & -5.175 & $0.01 *$ & 2006 \\
\hline Trade Balance Qatar & -7.404699 & -5.719 & -5.175 & $0.01^{*}$ & 1995 \\
\hline LOGGDP Bahrain & -5.733100 & -5.719 & -5.175 & $0.01^{*}$ & 2004 \\
\hline Inflation Bahrain & -8.269342 & -5.719 & -5.175 & $0.01^{*}$ & 1986 \\
\hline Trade Balance Bahrain & -11.44009 & -5.719 & -5.175 & $0.01 *$ & 2010 \\
\hline Oil Price & -8.482678 & -5.719 & -5.175 & $0.01^{*}$ & 2010 \\
\hline
\end{tabular}

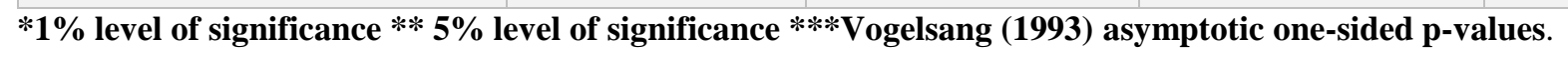

The results showed that most of the data series on the GDP, inflation and trade balance in the GCC countries were not stationary at the level (only inflation for UAE, GDP and inflation for Kuwait and GDP and Inflation for Bahrain were stationary at level. However, after taking the first difference all the series became stationary. This is depicted in the results as the test stats for the series were lower than critical values at $5 \%$ 
for most of the series as we performed the ADF test with the structural break ${ }^{6}$. However, the data is stationary at the $1^{\text {st }}$ difference and thus were integrated of order $I(1)$ which is very often the case with the economic and financial data. After the unit-root testing, in order determine an appropriate lag length we performed a lag length section test using alternative information criteria (Akaike Information Criterion, Schwarz Information Criterion, Hannan-Quinn Information Criterion). All the lag selection criteria unanimously suggested two as optimal numbers of lags which were then incorporated into the analysis in each case e. $^{7}$

\subsection{Impulse Response Function (IRF) Analysis}

After testing for stationarity, starting with the KSA, we performed the Impulse Response Function (IRF) analysis. The results for each of the six GCC countries are presented as follows:

\subsubsection{KSA.}

The results of the IRF presented in Figure 3 showed that the oil price shocks lead to a significant positive impact on the KSA's GDP. The impact of the shock was persistent for almost 5 periods (years) and was statistically significant for the first 3 years. It indicates that the KSA economy is heavily reliant on the dynamics of oil prices. An increase in oil prices leads to a significant improvement in output growth. This finding was in line with the study by Rebeca and Sánchez (2005) on oil exporting countries but contrary to the study by Hesary and Yoshino (2015) on oil importing countries (China, Japan and the United States). The results were support the empirical findings of Nasir et al (2018) on BRICS economies which showed that the oil exporting BRICS remembers (i.e. Brazil and Russia) were positively affected by positive oil price shocks.

\footnotetext{
${ }^{6}$ We based the number of lags in the ADF test on the Schwarz information criterion (SIC) as it is considered a best criteria in the presence of a structural breaks in the data series (See Asghar and Abid (2007).

${ }^{7}$ In order to conserve the space, the results of lag-selection test are not presented, however are available at request.
} 
Response of GDP to Oil Price Shocks

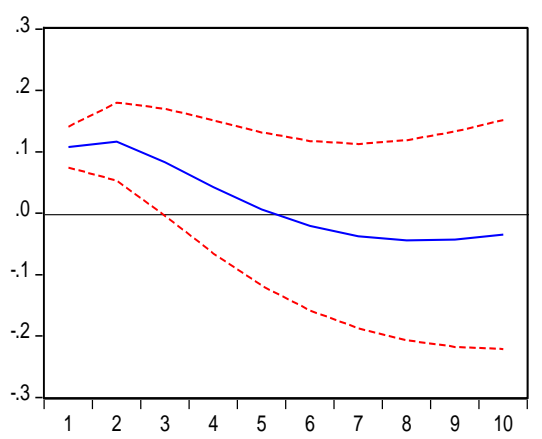

Response of Trade Balance to Oil Price Shocks

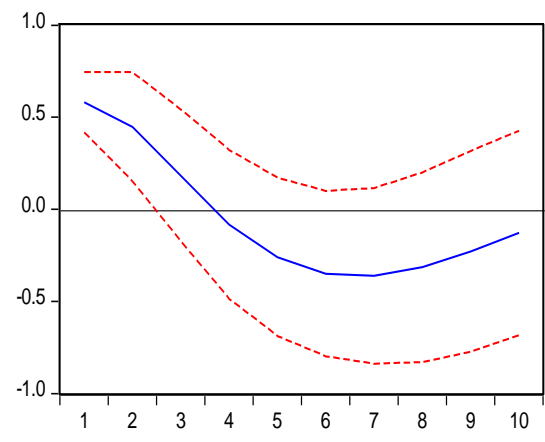

Response of Inflation to Oil Price Shocks

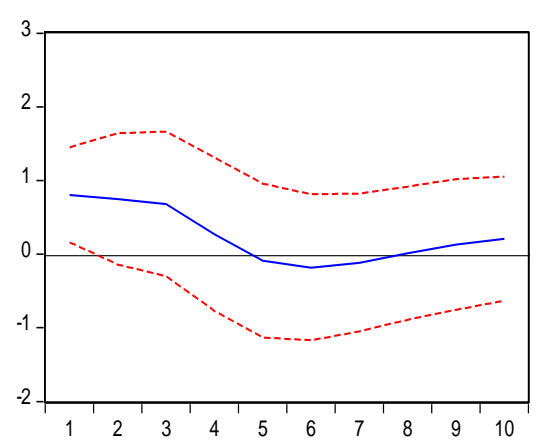

Response to Generalized One S.D. Innov ations \pm 2 S.E.

Figure 3: Response of KSA to Oil Price Shocks.

The same oil shock also led to a positive and significant response from the Trade balance which is intuitive as the oil is the major export of KSA. The impact persisted for over two periods (years) before fading and losing statistical significance. The findings were in line with the study by Rafiq et al. (2016) and Nasir et al (2018) on oil exporting countries and contrary to the findings by Kim and Loungani, (1992), Tiwari et al (2014) and Jackson (2016) on the oil importing countries which reported negative and insignificant results. Lastly, the oil shock also leads to a significant positive response from the domestic inflation which persisted for about 3 periods. The results are in line with the Leblanc and Chinn (2004) and study by Tang et al. (2010) on China and the most recent analysis by Choi et al (2018) on the developed and developing countries and Nasir et al (2018) on Brazil, China, India and South Africa. However, the finding on inflation is in contrast with the ones reported by Wu (2011) on China and Nasir et al on Russia. In specific to KSA, it could be associated with the demand side pressure due to the positive effects on output. Concomitantly, it has implication for the price stability as well as monetary authority in KSA to act accordingly.

\subsubsection{Bahrain}

The IRF analysis on Bahrain yielded the results of oil shocks which were similar to the KSA in direction of impact, although different in intensity. As shown in Figure 4, the positive oil shock led to a significant increase in the GDP which persisted for over six periods (years) longer than KSA. The Trade balance was 
also positively affected, though despite becoming statistically insignificant after 2 periods (years) the impact did not completely fade out for quite a few periods.
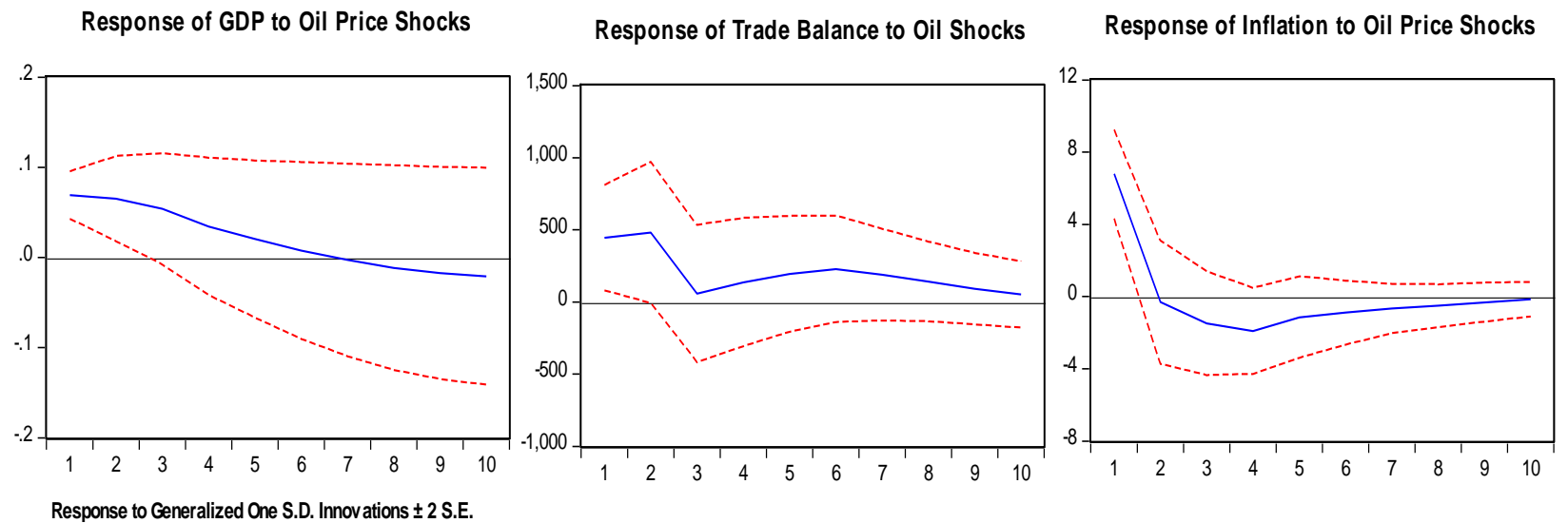

Figure 4: Response of Bahrain to Oil Price Shocks.

The impact of oil shock was positive on the domestic inflation rate and it was even more pronounced than

KSA, however, in terms of duration it was rather short-lived. On the whole, it implied that for Bahrain's economy the oil shocks could have short and long-term implications for growth and trade balance, however, for the inflation, the effects would be short term. In nutshell, the findings are in line with the results on KSA and can be contrasted against the existing evidence as discussed in the case of KSA. In the policy setting, it will imply that in the short-term there could be severe implications for price stability due to the oil shocks. Concomitantly, in the medium to long run, the output consequences are more severe and this aspect should be accounted for in Bahrain's policy response to oil shocks.

\subsubsection{Kuwait}

The results on Kuwait presented in Figure 5 showed that the impact of an oil price shock on the economic growth was positive and significant which even persisted for a prolonged period than previous two counterpart GCC members i.e. KSA and Bahrain. Similarly, the trade balance was also positively affected and effects were statistically significant and well pronounced. 
Response of GDP to Oil Price Shocks

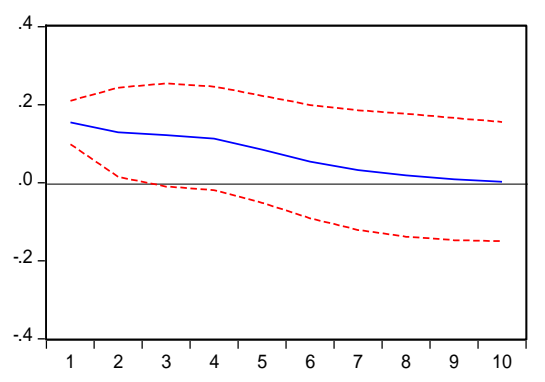

Response of Trade Balance to Oil Price Shocks

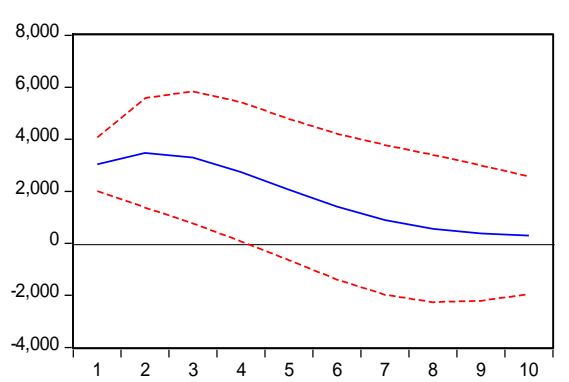

Response of Inflation to Oil Price Shocks

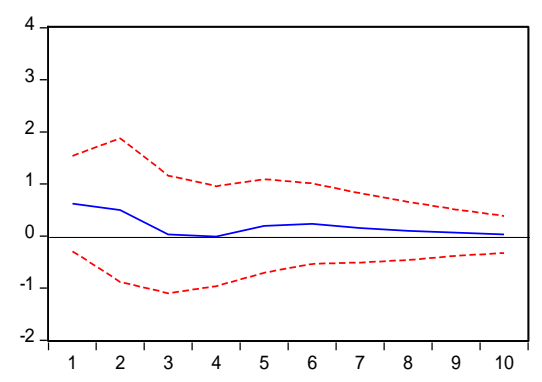

Response to Generalized One S.D. Innov ations \pm 2 S.E.

Figure 5: Response of Kuwait to Oil Price Shocks.

The results on inflation suggest that there were also positive effects on the inflation; however, they were comparatively very short-lived indicating that the positive oil shocks do not pose major challenges to price stability in Kuwait. In the context of policy setting, it would imply that the monetary policy shall consider this aspect for the long-term price as well as economic stability.

\subsubsection{Oman}

After Kuwait, we analysed the impact of oil price shocks on the economy of Oman. The results of IRF analysis are presented in Figure 6 which showed that the oil shocks had a significant positive impact on the economic growth. The impact was larger than other GCC countries analysed so far (KSA, Bahrain, and Kuwait). The Trade balance also showed a positive response to the oil price shock and the impact persisted for the whole horizon of analysis.
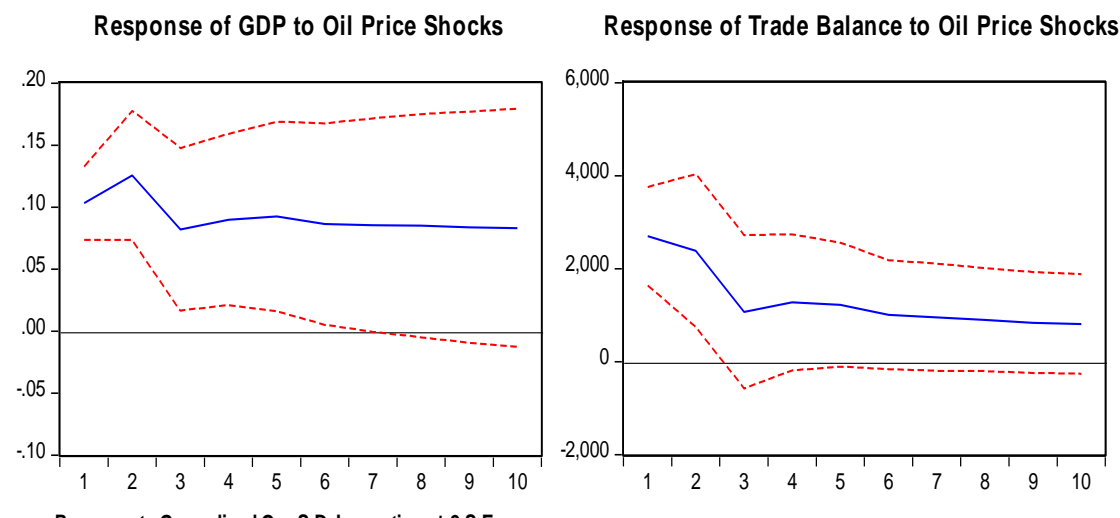

Response of Inflation to Oil Price Shocks

Response to Generalized One S.D. Innovations \pm 2 S.E.

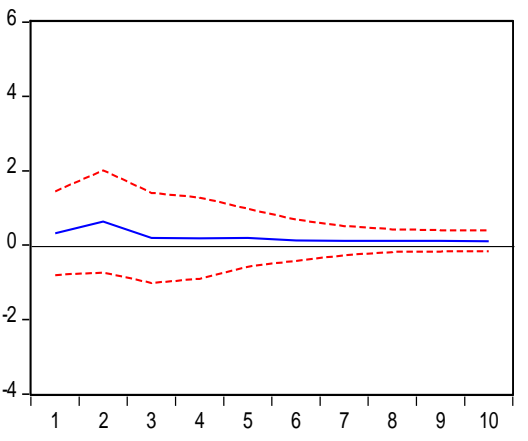

Figure 6: Response of Oman to Oil Price Shocks. 
The results on inflation suggest that the oil shock also led to some surge in the inflation; however, it was fairly modest implying that for Oman's economy the positive oil shock does not pose many challenges in terms of price stability. Hence, in policy setting in the face of a positive shock as the overly conservative response may not be the best choice, particularly when considering the fact that there are substantial gains in the real output growth.

\subsubsection{Qatar}

The results of the IRF analysis for Qatar are presented in Figure 7 which indicates that the oil price shocks had positive yet very mild effects on the Qatar economic growth. The response of the Trade balance was similar, positive yet very mild and not highly significant.
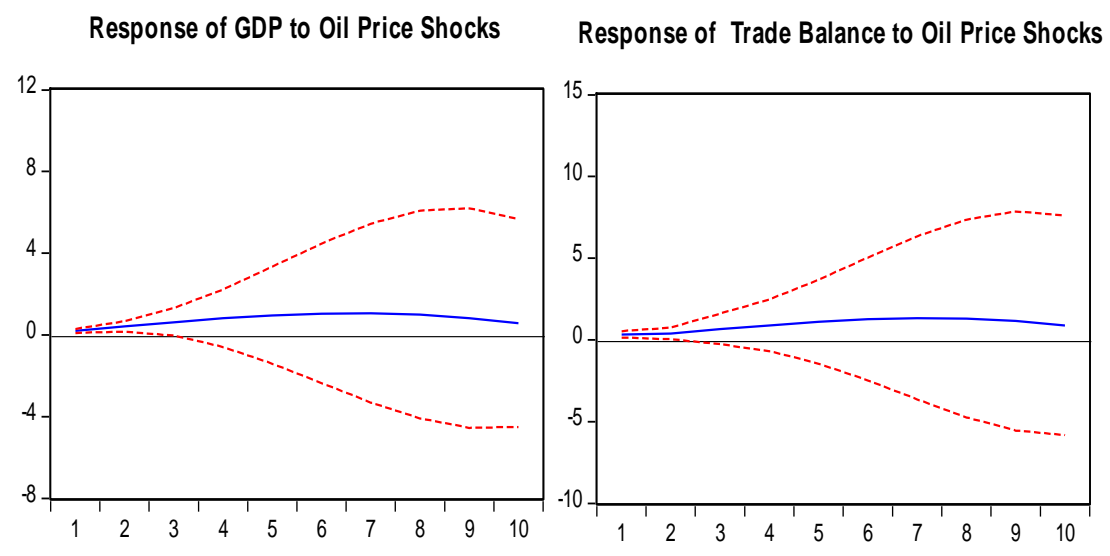

Response of Inflation to Oil Price Shocks

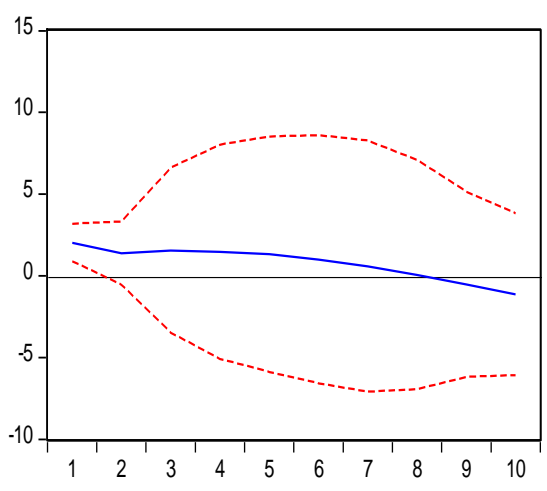

Response to Generalized One S.D. Innovations \pm 2 S.E.

Figure 7: Response of Qatar to Oil Price Shocks.

The inflation also showed a positive but mild and insignificant response to the oil price shocks. Although it implies that compared to the other counterpart GCC members Qatar's economy is less influenced by oil price shock, the findings are very intuitive as we consider the structure of Qatar's economy and export. The biggest export of Qatar is gas constituting over $60 \%$ of exports, concomitantly it is less affected by the oil price shock than other GCC countries e.g. KSA or Kuwait which have a greater component of oil in their revenues and exports. 


\subsubsection{UAE}

Lastly, we apply the SVAR framework on the UAE data and the results of the IRF analysis are presented in Figure 8. It showed that the impact of oil price shock was positive and significant for the UAE economic growth. The trade balance also positively affected by the positive oil price shocks, although the effects were comparatively short-lived, yet still the there was a significant persistence for 3 periods.
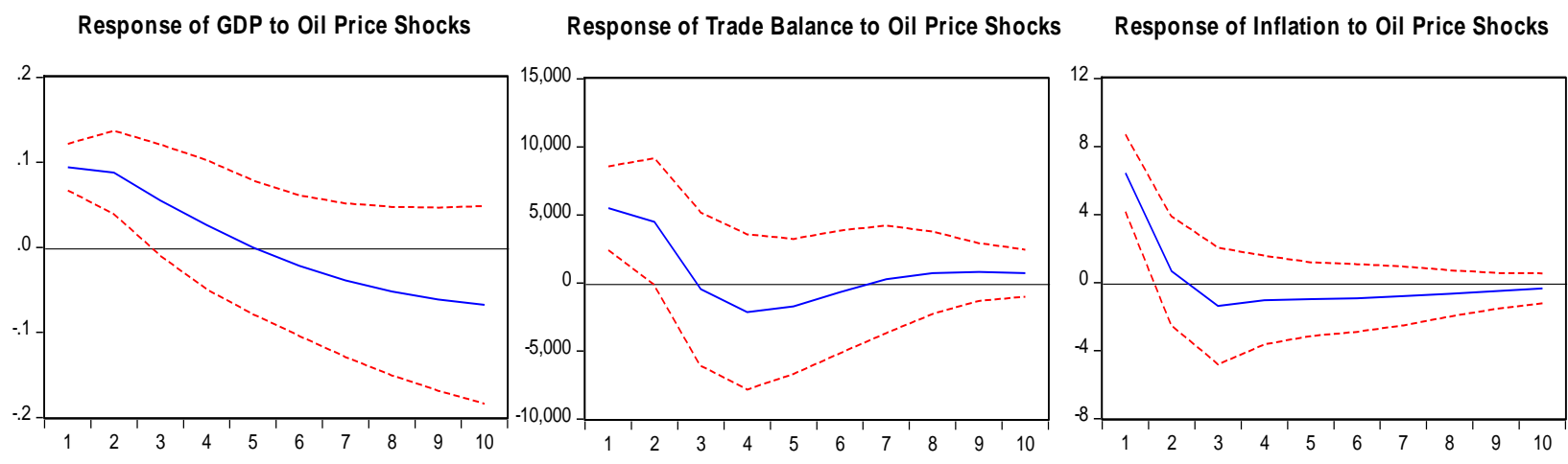

Response to Generalized One S.D. Innov ations \pm 2 S.E.

Figure 8: Response of UAE to Oil Price Shocks.

The inflation showed a sharp positive response to the oil price shocks; however, the effects became insignificant after two periods, implying that the oil shocks can have short-term implications for the price stability in the UAE. In terms of policy setting, it would imply that the monetary policy should consider the fact that any inflationary pressures due to the positive shocks would be short-lived and hence act accordingly to strike the right balance between inflation and output growth trade-off.

\subsection{Variance Decomposition Analysis}

After IRF, we performed the Variance Decomposition Analysis (VDA) for all of the GCC countries. In the same order as IRF, we started with the KSA and the results are presented in Figure 9. 

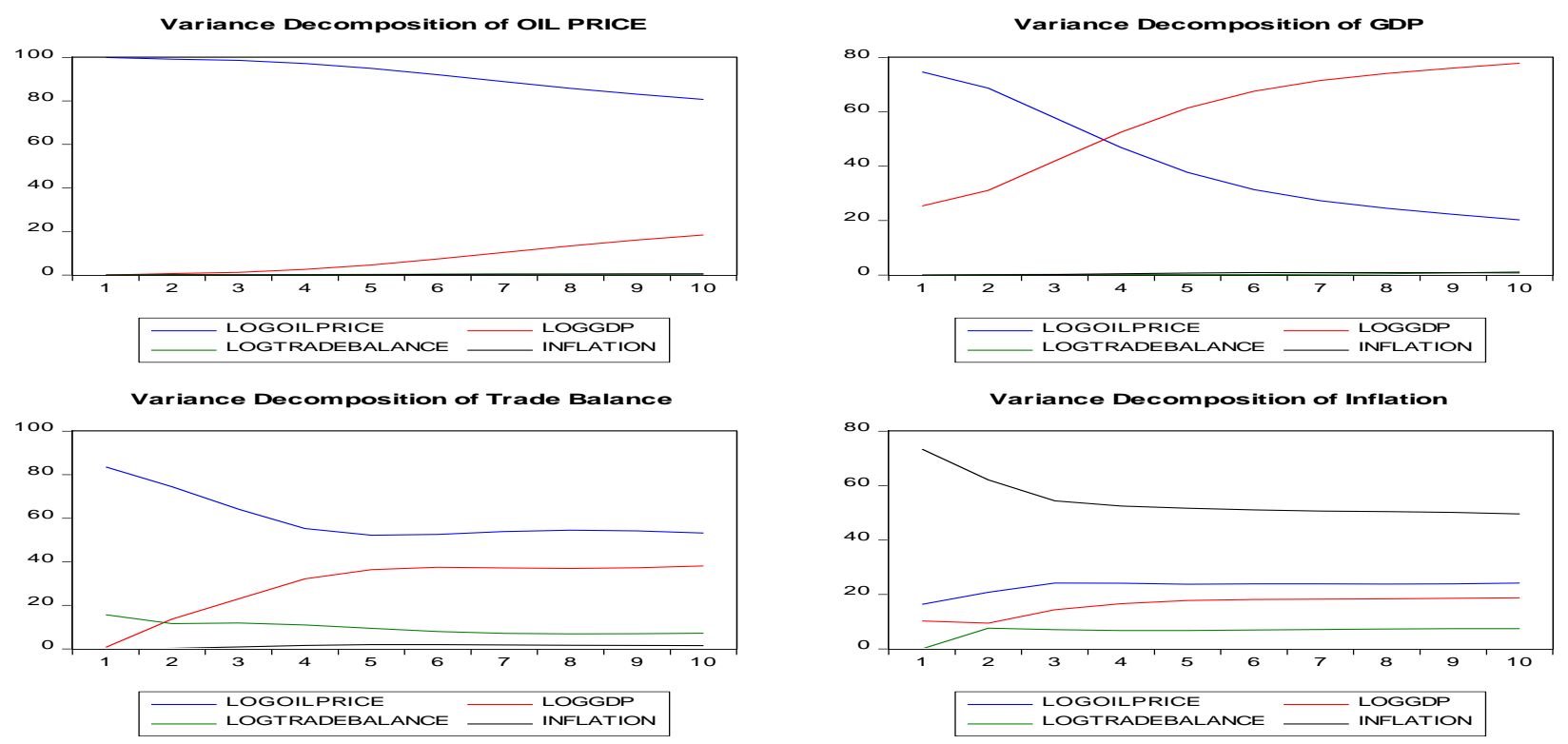

Figure 9: Variance Decomposition Analysis KSA

The VDA analysis for KSA showed that an oil price shock explained from $74 \%$ variation in the first year to $20 \%$ variation in the $10^{\text {th }}$ year in the annual GDP of KSA. For the Trade balance, the oil shock explained $83 \%$ variation in the first year to $53 \%$ variation in the tenth year. The oil shocks also explained $16 \%$ variation in the first year to $24 \%$ variation in the $10^{\text {th }}$ year. Next, we performed the VDA for Bahrain as results presented the Figure 10. 

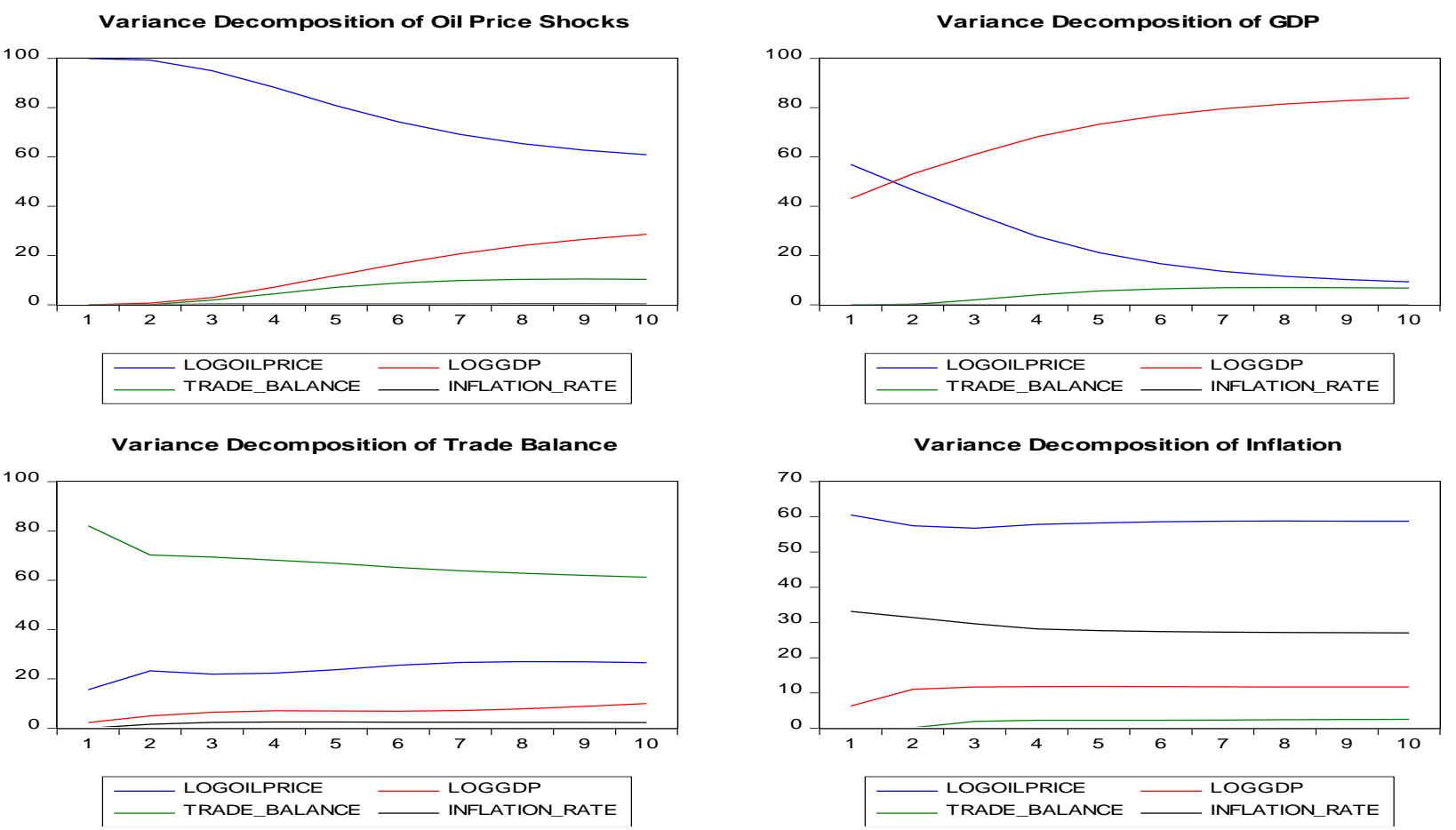

Figure 10: Variance Decomposition Analysis Bahrain

For Bahrain, the oil shocks explained about $56 \%$ variance in the GDP in the first year which diminished to $9.3 \%$ in the $10^{\text {th }}$ year. The trade balance showed about $15.61 \%$ variance in the $1^{\text {st }}$ year associated with oil shocks which increased to $26.5 \%$ by the $10^{\text {th }}$ year. The inflation showed a variance of about $60.53 \%$ due to the oil shock in the first year which reduced to $58.73 \%$ by the $10^{\text {th }}$ year. After Bahrain, we performed the VDA for Kuwait; the results are presented in Figure 11. 

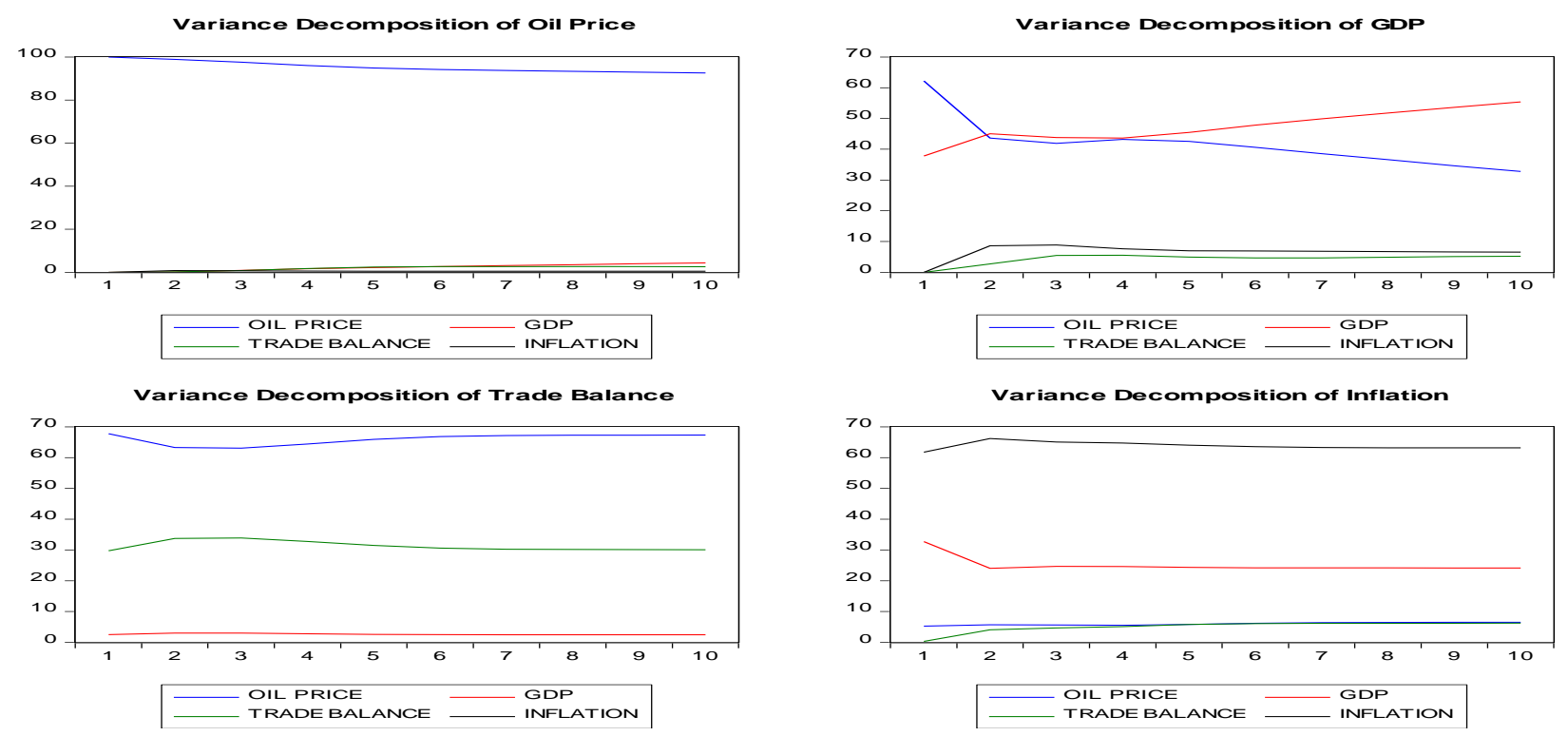

Figure 11: Variance Decomposition Analysis Kuwait

The VDA analysis for Kuwait showed that the oil price shocks explained about $62.19 \%$ variation in the GDP in the first year which decreased to about $32.78 \%$ in the $10^{\text {th }}$ year. The results on trade balance showed that the oil shocks explain about $67 \%$ percent variation which persisted around this level for the whole horizon of ten years. The inflation showed that only 5-6\% variation can be associated with the oil shock which complimented the results of IRF analysis for Kuwait on inflation. After Kuwait, we performed the VDA for Oman and the results are presented in Figure 12. 

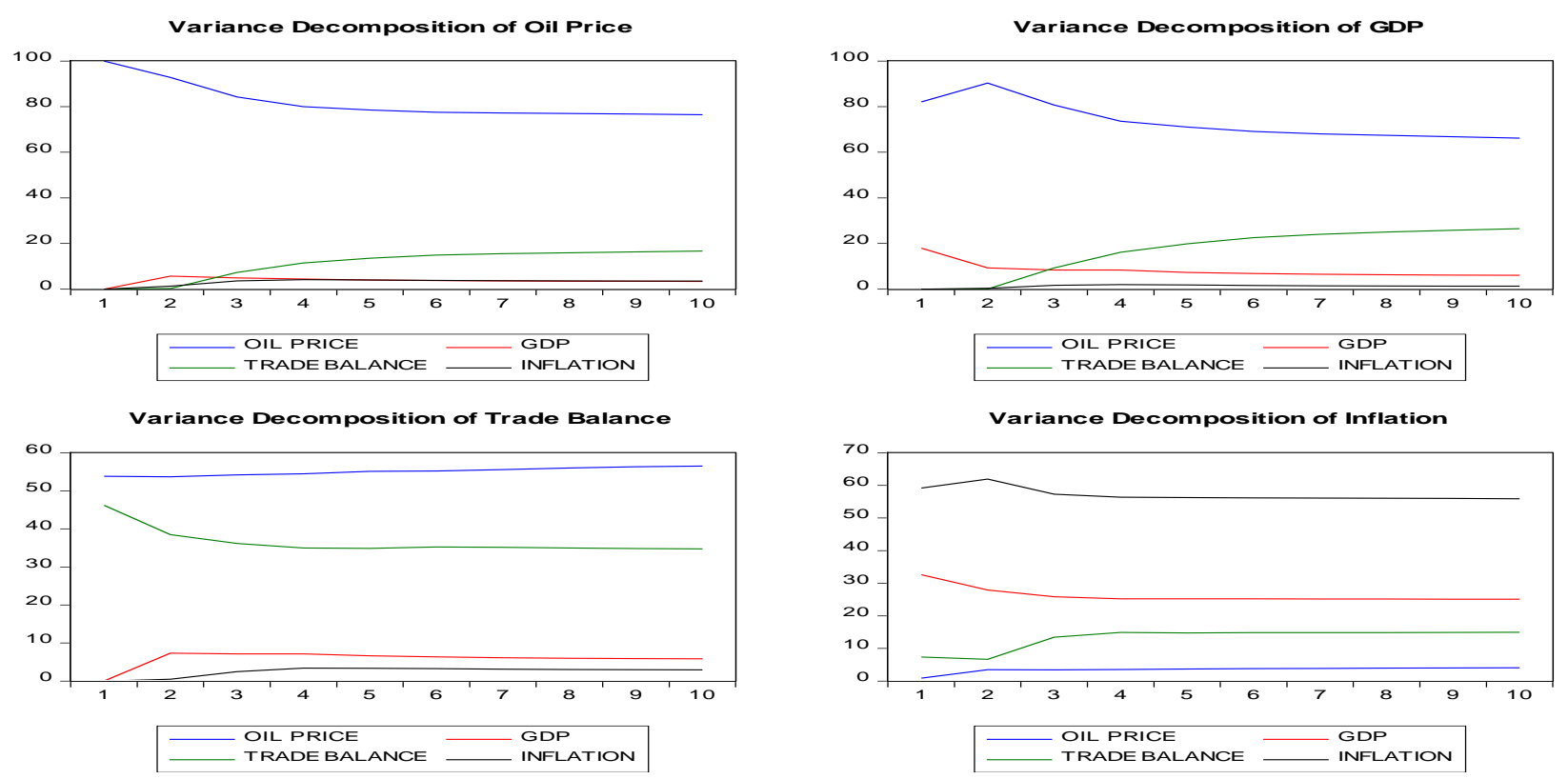

Figure 12: Variance Decomposition Analysis Oman

The results of VDA on Oman showed that the oil shocks explained the $82.09 \%$ variation in the GDP of Oman in the first year which decreased to about $66 \%$ in the $10^{\text {th }}$ year. On the other hand, $53 \%$ variation in the trade balance was associated with the oil shocks which increased to $56 \%$ by $10^{\text {th }}$ year. Interestingly only $0.9 \%$ variation in the inflation was explained by the oil shock in the $1^{\text {st }}$ year which increased to about $4 \%$ by the $10^{\text {th }}$ years. After Oman, we performed the VDA for Qatar and the results are presented in Figure 13. 

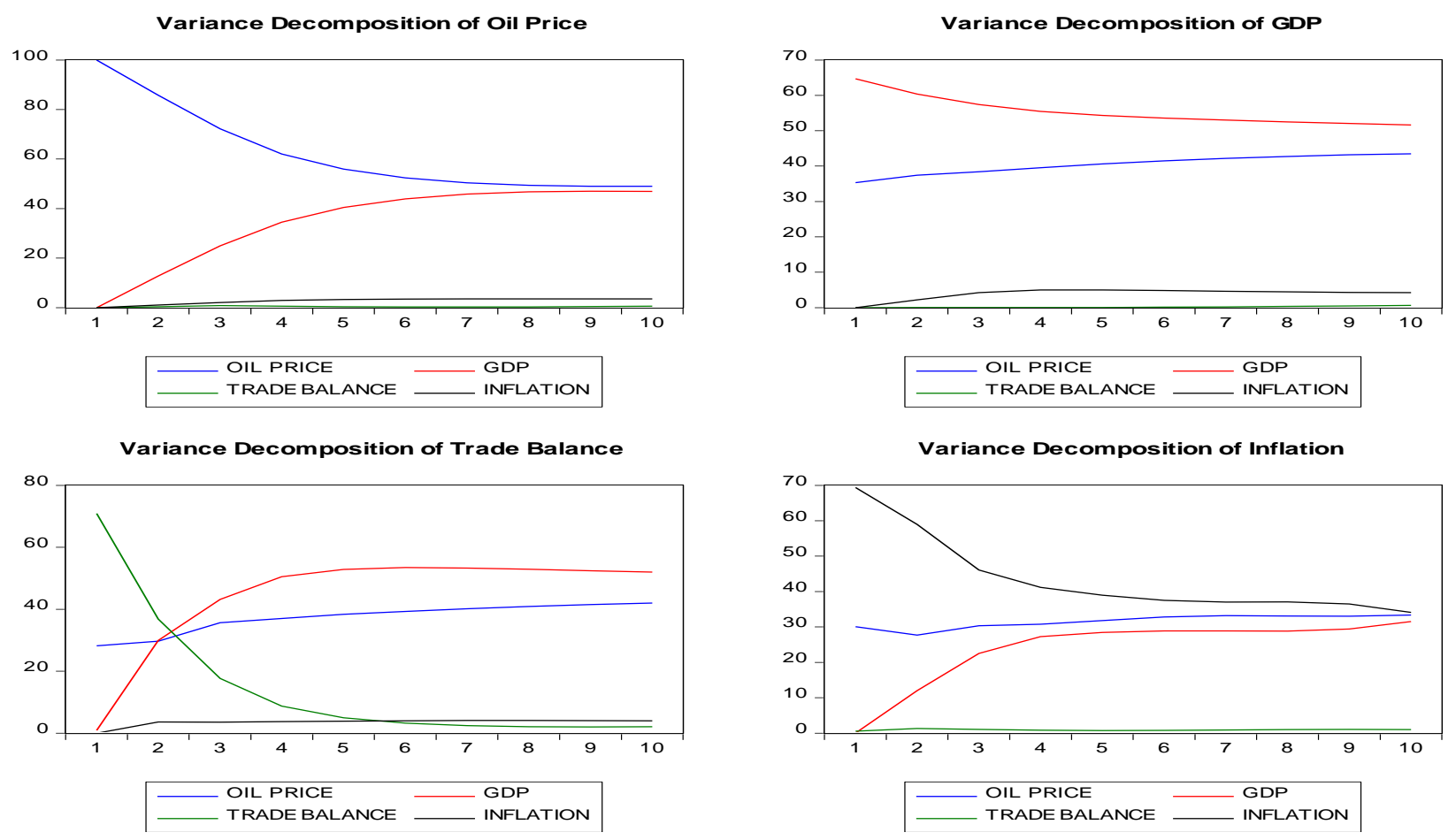

Figure 13: Variance Decomposition Analysis Qatar

The results on Qatar showed that oil shock explained about 35\% variation in the GDP in the first year which increased to $43 \%$ by the $10^{\text {th }}$ year. For the trade balance, the oil shock explained about $28 \%$ variation in the first year which increased to about $41 \%$ in the $10^{\text {th }}$ year. Inflation showed that the $30 \%$ variation can be associated with oil shock in the first year which increased to $33 \%$ by the $10^{\text {th }}$ year. Lastly, we performed the VDA for the UAE and the results are presented in Figure 14. 

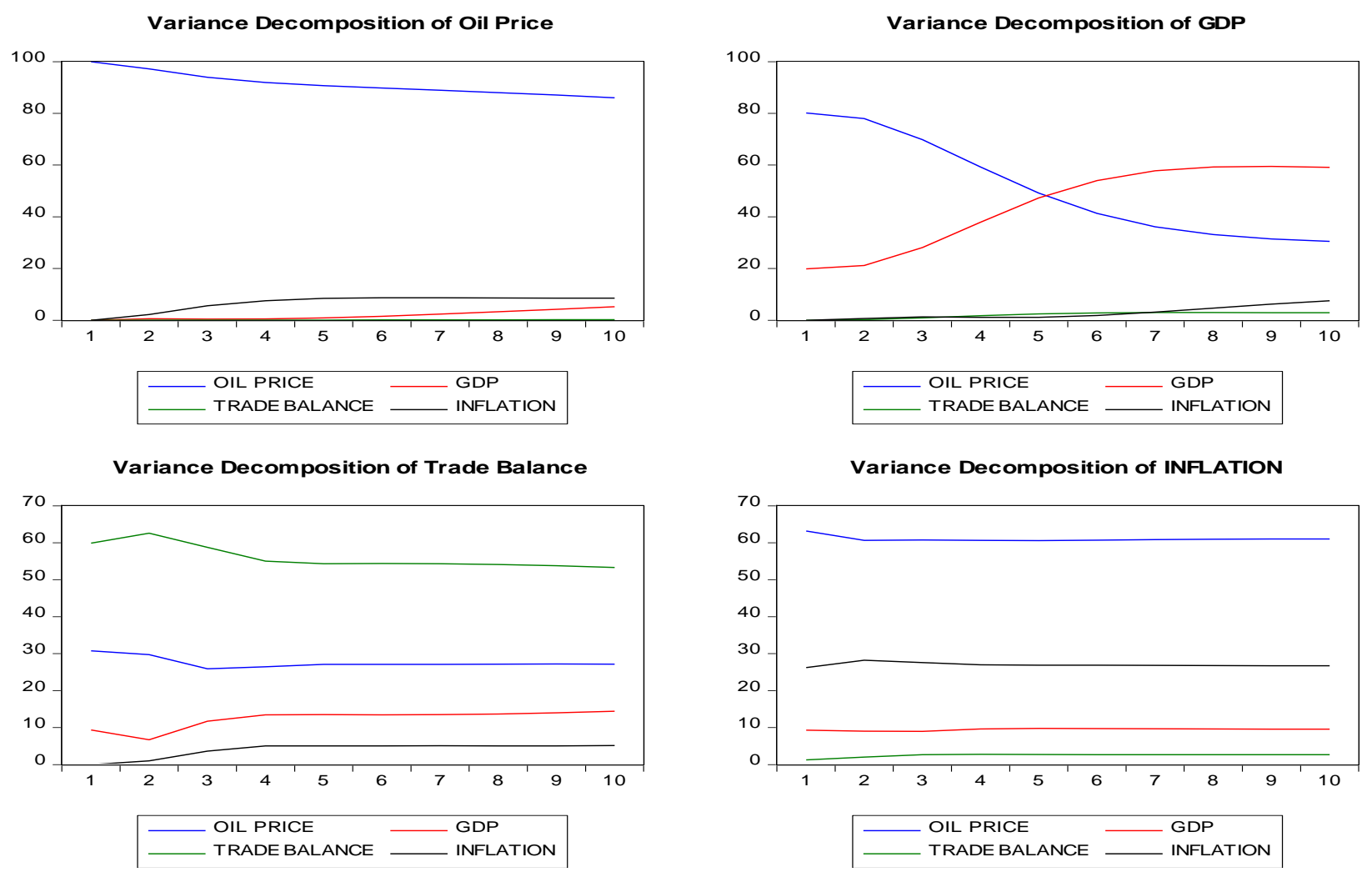

Figure 14: Variance Decomposition Analysis UAE

The VDA for UAE showed that oil shocks contribute to the $80 \%$ of the variation in the GDP in the first year which diminishes to about $30 \%$ by $10^{\text {th }}$ year. The oil shock explained about $30 \%$ variation in the $1^{\text {st }}$ year which slightly decreased in the long run to about $27 \%$ in the $10^{\text {th }}$ year. However, for inflation, the oil shocks explained about $63 \%$ variation in one year which persisted even in the long run to about $61 \%$ in ten years. on the whole the results suggested that the oil shocks contribute to significant variation in the output growth, inflation and trade balances of GCC countries, although the magnitude of varies among the GCC members. It leads us to conclude in the next section.

\section{Conclusion \& Policy Implications}

Based on empirical findings we can hereby conclude that although the oil price shocks have profound implications for all the member GCC countries, specifically in terms of economic growth, price and trade balance stability. Yet, there are some considerable differences among the responses of these countries to 
oil shocks which suggests that the transmission mechanism of oil shocks varies among GCC countries, at least in terms of the intensity. By comparison, it turned out that the KSA which is also the largest oil exporter among the GCC countries is also the one that is enormously affected by the oil shocks that significantly affect its economic growth, inflation and trade balance. On the other hand, in the case of Bahrain (which is the smallest producer of oil among the GCC family), the oil shocks had a greater impact on the GDP and trade balance in terms of persistence, whereas on inflation the effects were rather more pronounced than KSA, however, in terms of duration it was rather short-lived. It implied that Bahrain's economy could have short-term but severe implications for price stability due to the oil shocks. In the case of Kuwait, the effects of oil shocks were even more persistent than the KSA and Bahrain for output growth and trade balance. Interestingly, for inflation oil shocks were very short-lived indicating that the positive oil shocks do not pose major challenges to price stability in Kuwait. The results on Oman (which has the lowest nominal per capita in the GCC family) the impact of an oil shock on economic growth was larger than KSA, Bahrain, and Kuwait. Similarly, the effect on trade balance also showed a positive and prolonged reaction in response to the oil price shock. However, the impact on inflation was fairly modest which lead us to conclude that for Oman's economy the positive oil shocks lead to considerable gains in economic growth and improvement of external balance, yet they do not pose many challenges in terms of price stability. The empirical findings on Qatar which is also the richest economy of GCC and one of the richest economies in the world (based on per capita income) showed that the oil price shocks had positive yet very mild effects on economic growth, trade balance and inflation. It leads us to conclude that comparatively, the economy of Qatar is least influenced by the oil price shocks among GCC countries. Lastly, results on the UAE which is the second largest producer of oil and second richest economy (per capita based) in the GCC, lead us to conclude that the price shocks have positive effects on economic growth, trade balance and inflation. However, for trade balance and inflation, the influence was short-lived which implied that the oil shocks could have short-term implications for the price stability in the UAE. In the overall conclusion, there are major heterogeneities in the response of GCC economies to the oil shocks. There are also considerable differences in the short and long run responses of underlying economies which pose a variety of challenges 
and concomitantly policy implications for the economic and price stability. This implies that the stabilisation policies i.e. monetary and fiscal policies should take into account the idiosyncrasy of each GCC economy in policy formulation while responding to the oil shocks. As venues for further research in this area, researchers may employ the alternative empirical frameworks as well as perform the panel analysis which may have its own pros and cons. A comparative analysis of GCC by incorporating the intuitional and political factors may also be an interesting extension. 


\section{References}

Amano, R. Van Norden, S. (1998). Oil prices and the rise and fall of the US real exchange rate. Journal of International Money and Finance, Volume 17 (2), pp. 299-316.

Albaity, M. Mustafa, H. (2018), International and Macroeconomic Determinants of Oil Price: Evidence from Gulf Cooperation Council Countries, International Journal of Energy Economics and

Policy, Volume 8(1), pp. 69-81.

Algahtani, G. (2016). The Effect of Oil Price Shocks on Economic Activity in Saudi Arabia: Econometric Approach, International Journal of Business and Management, Volume 11 (8), pp. 124-133.

Al-mulali, U. Sab, C. Normee, C. (2010). The Impact of Oil Shocks on Qatar's GDP. Munich Personal RePEc Archive, pp. 1 -24.

Atlas (2017), Qatar Exports, Available at https://atlas.media.mit.edu/en/resources/data/ accessed on $5^{\text {th }}$ December 2017.

Alodadi, A. Benhin, J. (2015), Long Term Economic Growth in Oil-Rich Saudi Arabia: What is the role for non-oil sectors? Economic Issues, Volume 20 (1) pp. 109-129.

Arouri, M. Lahiani, A. Nguyen, D. (2011), Return and volatility transmission between world oil prices and stock markets of the GCC countries, Economic Modelling, Volume 28 (4), pp. 1815-1825.

Arouri, M. Rault, C. (2012), Oil prices and stock markets in GCC countries: empirical evidence from panel analysis, International Journal of Finance \& Economics, Volume 17 (3), pp. 242-253.

Banerjee, A., Lumsdaine, R. L. Stock, J. H. (1992). Recursive and Sequential Tests of the Unit Root and Trend-Break Hypothesis: Theory and International Evidence, Journal of Business and Economic Statistics, Volume 10 (3), pp. 271-287.

Bataa, E. (2010), Impacts of oil shocks: Implications for GCC economies. Gulf One Lancaster Center for Economic Research.

Bernanke, B. S. Gertler, M. Watson, M. Sims, C. A. Friedman, B. M. (1997). Systematic monetary policy and the effects of oil price shocks, Brookings papers on economic activity, Volume 28 (1), pp. 91-157.

Baumeister, C. Kilian, L. (2016), Forty Years of Oil Price Fluctuations: Why the Price of Oil May Still Surprise Us, Journal of Economic Perspectives, Volume 30 (1), pp. 139-160.

Baumeister, C. Kilian, L. (2016), Understanding the Decline in the Price of Oil since June 2014, Journal of the Association of Environmental and Resource Economists, Volume 3 (1), pp. 131-158.

Benedictow, A., Fjaertoft, D. Løfsnæs, O. (2013). Oil dependency of the Russian economy: An econometric analysis, Economic Modelling, Volume 32 (5) , pp. 400-428.

Berument, M. H. Ceylan, N. B. Dogan, N. (2010), The impact of oil price shocks on the economic growth of selected MENA countries. The Energy Journal, volume 31 (1), pp. 149 -176.

Arezki, R. Blanchard, A.(2014), Seven Questions about the recent oil price slump, the IMF Blog, available at https://blogs.imf.org/2014/12/22/seven-questions-about-the-recent-oil-price-slump/. 
Bohi, D. (2016), Energy Price Shocks and Macroeconomic Performance. Oxon: Routledge.

Boldanov, R. Degiannakis, S. Filis, G. (2016), Time-varying correlation between oil and stock market volatilities: Evidence from oil-importing and oil-exporting countries, International Review of Financial Analysis, Volume 48, pp. 209 - 220.

Bordoff, J. Stock, J. (2014), The Implications of Lower Oil Prices for the US Economy amid the Shale Boom, Centre for Global Energy Policy, pp. 1-5.

Bremmer, I. (2016), Saudi Arabia Will Be the Big Loser from the Plunge In Oil Prices, The Time, $21^{\text {st }}$ January 2016.

Bryant, S. (2015), How Cheap Oil Will Hurt the Saudi Arabian Economy, available at https://www.investopedia.com/articles/investing/091515/how-cheap-oil-will-hurt-saudi-arabian-

economy.asp, accessed on $1^{\text {st }}$ December 2017.

Cashin, P., Mohaddesb, K., Raissic, M. and Raissia, M. (2014). The differential effects of oil demand and supply shocks on the global economy, Energy Economics, Volume 44, pp. 113-134.

Choi, S. Furceri, D. Loungani, P. Mishra, S. Poplawski-Ribeiro, M. (2018), Oil prices and inflation dynamics: Evidence from advanced and developing economies, Journal of International Money and Finance, Volume 82, pp. 71-96.

Cunado, J., De Gracia, F. P. (2005). Oil prices, economic activity and inflation: evidence for some Asian countries, The Quarterly Review of Economics and Finance, Volume 45(1), pp. 65-83.

Dibooglu, S. Aleisa, E. (2004). Oil Prices, Terms of Trade Shocks, And Macroeconomic Fluctuations in Saudi Arabia, Contemporary Economic Policy, Volume 22 (1), pp. 50- 62.

Dornbusch, R., Fischer, S. and Startz, R. (2001). Macroeconomics, 8th edition, McGraw-Hill.

Dreger, C., Kholodilin, K. A., Ulbricht, D. and Fidrmuc, J. (2016). Between the hammer and the anvil: The impact of economic sanctions and oil prices on Russia's ruble, Journal of Comparative Economics, Volume 44, pp. 295-308.

Dülger, F., Lopcu, K., Burgaç, A. Balli, E. (2013). Is Russia suffering from Dutch Disease? Cointegration with Structural break, Resources Policy, 38 (4), pp. 605-612.

Dutta, A. Nikkinen, J. Rothovius, T. (2017), Impact of oil price uncertainty on Middle East and African stock markets, Energy, Volume 123, pp. 189-197.

Economou, A. Agnolucci, P. (2016), Oil Price Shocks: A Measure of the Exogenous and Endogenous Supply Shocks of Crude Oil, In SPE Annual Technical Conference and Exhibition, Society of Petroleum Engineers, pp. $1-42$.

Eltony, M. N. and Al-Awadi, M. (2001), Oil price fluctuations and their impact on the macroeconomic variables of Kuwait: a case study using a VAR model. International Journal of Energy Research , 25: pp. 939-959.

Farzanegan, M. R. Markwardt, G. (2009), The effects of oil price shocks on the Iranian economy, Energy Economics Volume 31(1), pp. 134-151. 
Fattouh, B. Sen. A. (2016). Saudi Arabia Oil Policy: More than Meets the Eye?. The Oxford Institution for Energy Studies, pp. $1-27$.

Fayyad, A. Daly, K. (2011), The impact of oil price shocks on stock market returns: comparing GCC countries with the UK and USA, Emerging Markets Review, Volume 12 (1), pp. 61-78.

Ferderer, J. (1996). Oil price volatility and the Macroeconomy, Journal of Macroeconomics, Volume 18 (1), pp. 1-26.

Fox, A. J. (1972). Outliers in Time Series, Journal of the Royal Statistical Society B, Volume 34 (3), pp. $350-363$.

Glasure,Y. U. Lee, A. R. (2002), The impact of oil prices on income, International Advances in Economic Research, Volume 8 (2), pp. 148-154 .

Gokmenoglu, K. Azin, V. Taspinar, N. (2015), The Relationship between Industrial Production, GDP, Inflation and Oil Price: The Case of Turkey, Procedia Economics and Finance, Volume 25, pp 497-503.

Taghizadeh-Hesary, F. Yoshino, N. (2015) 5. Macroeconomic Effects of Oil Price Fluctuations on Emerging and Developed Economies in a Model Incorporating Monetary Variables. ADBI Working Paper 546. Tokyo: Asian Development Bank Institute.

Hou, Z. Keane, J. Kennan, J. Willem te Velde, D. (2015), The Oil Price Shock 2014, The Overseas Development Institute (ODI), Working paper No. 415.

Husain, A. M. Arezki, R. Breuer, P. Haksar, V. Helbling, T. Medas, P. (2015), Global Implications of Lower Oil Prices, IMF Staff Discussion note, SDN/15/15.

Idrisov, G., Kazakova, M. and Polbin, N. (2015). A Theoretical interpretation of the oil prices impact on economic growth in contemporary Russia, Russian Journal of Economic, Volume 1 (3), pp. 257-272.

Jackson, J. K. (2016), U.S. Trade Deficit and the Impact of Changing Oil Prices, Congressional Research Service, RS22204.

Jiménez-Rodríguez, R. Sánchez, M., 2005. Oil price shocks and real GDP growth: empirical evidence for some OECD countries. Applied economics, Volume 37(2) pp. 201-228.

Jouini, J. Harrathi, N. (2014), Revisiting the shock and volatility transmissions among GCC stock and oil markets: A further investigation. Economic Modelling. Volume 38 (2), pp. 486-494.

Kennedy, C (2016), Despite Low Oil Prices, Kuwait Plans To Invest $\$ 42$ Billion By 2022, Oil Price, available at https://oilprice.com/Energy/Crude-Oil/Despite-Low-Oil-Prices-Kuwait-Plans-To-Invest-42Billion-By-2022.html.

Kilian, L. Park, C. (2009). The impact of oil price shocks on the US stock market, International Economic Review, Volume 50 (4), pp. 1267-1287.

Kilian, L., Rebucci, A. and Spatafora, N. (2009). Oil shocks and external balances, Journal of International Economics, Volume 77 (2), pp. 181-194. 
Kilian, L. and Vigfusson, R. J. (2011). Are the responses of the U.S. economy asymmetric in energy price increases and decreases? Quantitative Economics, 2, 419-453.

Kilian, L. (2014), Oil price shocks: causes and consequences. Annual Review of Resource Economics, Volume 6: pages 133-154.

Kim, I-M. Loungani, P. (1992). The Role of Energy in Real Business Cycle Models. Journal of Monetary Economics, 29, pp. 173-189.

Kim, S. Willett, T. (2000), Is the negative correlation between inflation and growth real? An analysis of the effects of the oil supply shocks, Applied Economics Letters, Volume 7 (3), pp. 141-147.

Kim, W. Hammoudeh, S. (2013), Impacts of global and domestic shocks on inflation and economic growth for actual and potential GCC member countries, International Review of Economics and Finance, volume 27 (C), pp. 298-317.

Macalister, T. (2011), Background: What caused the 1970s oil price shock? Available at https://www.theguardian.com/environment/2011/mar/03/1970s-oil-price-shock

Maghyereh, A. Al-Kandari, A. (2007) "Oil prices and stock markets in GCC countries: new evidence from nonlinear cointegration analysis", Managerial Finance, Volume 33 (7), pp. 449-460.

Mahboub, A. Ahmad, H. (2016). The effect of oil price shocks on the Saudi manufacturing sector, Topics in Middle Eastern and African Economies Volume 18 (2), pp. 185 -200.

Manama, (2016), Low oil prices to impact Bahrain growth. NBK Trade Arabia, available at http://www.tradearabia.com/news/BANK_304800.html.

Cologni, A. Manera, M. (2008), Oil prices, inflation and interest rates in a structural cointegrated VAR model for the G-7 countries, Energy Economics, Volume 30 (3), pp. 856-888.

Masan, S. (2016), Oil and macroeconomic policies and performance in Oman. DBA thesis, Loughborough University Institutional Repository.

Hutt, R. (2016), Which economies are most reliant on oil? World Economic Forum, available at https://www.weforum.org/agenda/2016/05/which-economies-are-most-reliant-on-oil/.

Kuboniwa, M. (2014). A comparative analysis of the impact of oil prices on oil-rich emerging economies in the Pacific Rim, Journal of Comparative Economics, 42, pp. 328-339.

Le, T. H. Chang, Y. (2013). Oil price shocks and trade imbalances. Energy Economics, 36, pp. 78-96.

Mimouni, K., Charfeddine, L. Al-Azzam, M. (2016), 'Do oil producing countries offer international diversification benefits? Evidence from GCC countries, Economic Modelling, Volume 57, pp. 263-280.

Mironov, V. V. Petronevich, A. V. (2015). Discovering the signs of Dutch disease in Russia. Resources Policy, 46, pp. 97-112.

Murshed, H. Nakibullah, A. (2015), Price level and inflation in the GCC countries, International Review of Economics and Finance, Volume 39, pages 239-252

Nakov, A. Nuño, G. (2013), Saudi Arabia and the Oil Market, the Economic Journal, Volume 123, pp. 1333-1362. 
Narayan, P. K. Sharma, S. (2011), New Evidence on Oil Price and Firm Returns, Journal of Banking and Finance, Volume 35 (12), pp. 3253-3262,

Nasir, M. A. Naidoo, L. Shahbaz, M. Nii, A. (2018) Oil Price Shocks \& Implications for Macroeconomy: A Comparative Analysis of BRICS, Energy Economics, Volume 76, pp. 76-88.

Nusair, S. A. (2015), The effects of oil price shocks on the economies of the Gulf Co-operation Council countries: Nonlinear analysis, Energy Policy, Volume 91 (4) pp. 256-267.

Onour, I. A. (2016), Crude oil price changes: Common trend and common cycle features. Topics in Middle Eastern \& North African Economies, Volume 18 (2), pp. 130-141.

Park, C. Chung, M. Lee. S. (2011). The effects of oil price on regional economies with different production structures: A case study from Korea using a structural VAR model, Energy Policy, Volume 39(12), pp 8185-8195.

Pierru, A. Matar, W. (2014), The Impact of Oil Price Volatility on Welfare in the Kingdom of Saudi Arabia: Implications for Public Investment Decision-making, the Energy Journal 35(2), pp. 97-116.

Peersman, G. (2005). What caused the early millennium slowdown? Evidence based on vector autoregressions. Journal of Applied Econometrics, Volume 20(2) pp.185-207.

Peersman, G. Van Robays, I. (2009). Oil and the Euro area economy, Economic Policy, Volume 24(60), pp. 603-651.

Perron, P. (1989), The great crash, the oil price shock and the unit root hypothesis, Econometrica, Volume 57, pp. 1361-1401.

Qaiser,M. Shabbir, M. Syed , A. (2016), Oil demand and price elasticity of energy consumption in the GCC countries: A panel cointegration analysis. Business and Economic Horizons, Volume 12 (2), pp 63-74.

Ranganathan, T. Ananthakumar, U. (2010), Unit Root Test: Give It A Break, The 30th International Symposium on Forecasting, International Institute of Forecasters.

Rafiq, S., Sgro, P. Apergis, A. (2016). Asymmetric Oil shocks and external balances of major oil exporting and importing countries, Energy Economics, pp. 42-50.

Rasmussen, T. Roitman, A. (2011), Oil shocks in a global perspective: Are they really that bad? IMF Working Paper No. 11/194.

Rautava, J. (2004). The role of oil prices and the real exchange rate in Russia's economy - a cointegration approach, Journal of Comparative Economics, Volume 32, pp. 315-327.

Roubini, N. Setser, B. (2004), The effects of the recent oil price shock on the U.S. and global economy. Research Associate, Global Economic Governance Programme, University College Oxford.

Sahoo, S. (2015) Debt burden to grow heavier for Bahrain if oil prices remain low, says ratings agency S\&P. The National Business, available at https://www.thenational.ae/business/debt-burden-to-growheavier-for-bahrain-if-oil-prices-remain-low-says-ratings-agency-s-p-1.96165.

Sfakianakis, J. (2014), Oil Prices and the GCC: The resilient and the Less So, Ashmore-The Emerging View, pp. 1 - 5. 
Simmons, M. R. (2013), Twilight in the desert: the coming Saudi oil shock and the world economy, Hoboken, N.J., Wiley.

Singh, T. (2017), Impact of oil prices on Qatar economy, available https://www.tejinderworld.com/perspective/impact-of-oil-prices-on-qatar-economy/115.

Statista. (2016), Statista - The portal for statistics, available at https://www.statista.com/

Sturm, M. Strasky, J. S. Adolf, P. A. (2008). The Gulf Coopertation Council Countries Economic Structures, Recent Developments and Role in the Global Economy. European Central Bank, Occasional Paper series No 92.

Tang, W., Wu, L. and Zhang, Z. (2010). Oil price shocks and their short- and long-term effects on the Chinese economy, Energy Economics, Volume 32 (1), S3-S14.

Thompson, K. A. Al-Aujan, D.T. Al-Nazha, R. Al-Lwaimy, S. Al-Shehab,S (2012), Saudi Arabia's Economic Diversification: A Case Study in Entrepreneurship, Journal of Management and Business Research, Volume 2 (2), pp. 37-40.

Tiwari, A. K. Arouri, M. Teulon, F. (2014) "Oil prices and trade balance: A frequency domain analysis for India," Economics Bulletin, volume 34(2), pp. 663-680.

Tsay, R. S. (1988). Outliers, Level Shifts and Variance Changes in Time Series, Journal of Forecasting, Volume 7 (1), pp 1-20.

Tverberg, G. E. (2012), Oil supply limits and the continuing financial crisis, Energy, Volume 37 (1), pp. 27-34.

Ulussever, T. Demirer, R. (2017), Investor herds and oil prices evidence in the Gulf Cooperation Council (GCC) equity markets, Central Bank Review, Volume 17 (3), pp. 77-89.

Verleger, Jr. P.K. (1980), The U.S. Petroleum Crisis of 1979, Brookings Papers on Economic Activity, 2, pp. 463-476.

Vogelsang, T. Perron, P. (1998). Additional Tests for a Unit Root Allowing for a Break in the Trend Function at Unknown Time, International Economic Review, Volume 39 (4) pp. 1073-1100.

Vohra, R. (2017), The Impact of Oil Prices on GCC Economies, International Journal of Business and Social Science, Vol. 8 (2), pp. 7-14.

Wahbah, Y. Assaad, E. (2016), The impact of decreasing oil prices on the GCC RHC market, Ernest and Young, available at http://www.ey.com/Publication/vwLUAssets/ey-decreasing-oil-prices-impact-the-gccrhc-market/\$FILE/ey-decreasing-oil-prices-impact-the-gcc-rhc-market.pdf

Wang, Y., Wu, C. and Yang, L. (2013). Oil price shocks and stock market activities: Evidence from oilimporting and oil-exporting countries. Journal of Comparative Economics, 41, pp. 1220-1239.

Wu, L. Li, J. Zhang, Z.X. (2013), Inflationary effect of oil-price shocks in an imperfect market: A partial transmission input-output analysis, Journal of Policy Modeling, Volume 35 (2), pp. 354-369,

Zivot, E. Andrews, K. (1992). Further Evidence on The Great Crash, The Oil Price Shock, and The Unit Root Hypothesis, Journal of Business and Economic Statistics, Volume 10 (10), pages 251-270. 
